\title{
IN ORDER TO INCREASE INNOVATIVE ORGANIZATION IN TURKEY, THE CONCEPT OF INNOVATION THROUGH TRAINING SYSTEMS AND SOLUTIONS AN OVERVIEW
}

\author{
DOI: 10.17261/Pressacademia.2018.844
}

JMML- V.5-ISS.2-2018(4)-p.124-139

\section{Senem Altan}

Okan Üniversitesi, Uygulamalı Bilimler Fakültesi, Yönetim Bilişim Sistemleri Bölümü, İstanbul, Türkiye. senem.altan@okan.edu.tr, ORCID: 0000-0003-0264-0821

\section{To cite this document}

Altan, S. (2018). Türkiye'deki yenilikçi örgütleri arttırabilmek için, eğitim sistemine inovasyon kavramı üzerinden bir bakış ve çözüm. Journal of Management, Marketing and Logistics (JMML), V.5(2), p.124-139.

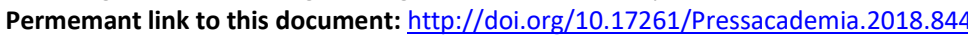

Copyright: Published by PressAcademia and limited licenced re-use rights only.

\begin{abstract}
Purpose- The purpose of this research; 4.0 In the context of industry dynamics underlying the digital transformation of inovasyonel perspective, the effects on innovation and competitiveness index in Turkey organizational structure of the education system in order to examine the relationship between missing the point.

Methodology- The methodology of the research; is based on synthesized interpretation of the information obtained by searching the literatures of domestic and foreign sources in the field related to the general purpose of the study.

Findings- The relevant literature is examined based on the fact that the existence of organizations with limited innovative organization structures in the country and subordination in the order of international innovation index according to the world in general and the organizations that can not exhibit innovative performance accordingly are based on the missing points in the education system. The lack of education system and the problems; It has also been determined that the business world has pointed to the lack of innovative organizations as a result of its impact on the context of industry, society and human interaction.

Conclusion- Turkey's current weaknesses in the education system in order to clarify the innovation and competitiveness index; it is envisaged that industry 4.0 implementations will be able to guide the implementation of effective approaches and planned actions, making it possible to encourage the need for more strategic and industrial approaches within society as a whole.
\end{abstract}

Keywords: Digital transformation dynamics, education system, industry 4.0, innovation, innovative organization JEL Codes: I20, L10, P36

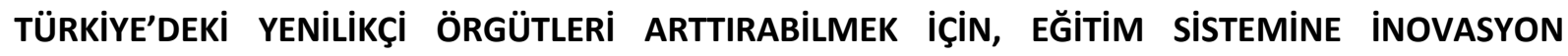 KAVRAMI ÜZERINDEN BIR BAKIŞ VE ÇÖZÜM ÖNERILERi}

\section{ÖZET}

Amaç- Bu araştırmanın amacı; endüstri 4.0 bağlamında dijital dönüşüm dinamiklerinin temelini oluşturan inovasyonel bakış açısının, Türkiye'deki örgüt yapısına etkileri ile Türkiye'nin inovasyon ve rekabetçilik endekslerindeki sıralamasının eğitim sistemindeki eksik noktalarla ilişkisinin incelenmesidir.

Metodoloji- Araştırmanın metodolojisi; çalışmanın genel amacına yönelik kavramlarla ilgili alan yazındaki yurtiçi ve yurtdışı kaynaklarda yer alan literatürün taranmasıyla elde edilen bilgilerin, sentezlenerek yorumlanmasına dayandırılmıştır.

Bulgular- Alan yazın incelenmesiyle, dünya geneline göre ülkemizdeki yenilikçi örgüt yapılarının kısıtlı sayıda kalması ve ülkelerarası inovasyon endeks sıralamasında alt sıralarda yer alması, buna bağlı olarak da inovatif performans sergileyemeyen örgütlerin varlığı, eğitim sistemindeki eksik noktalarla temellendirilmesidir. Eğitim sistemindeki eksiklik ya da sorunların; iş dünyasında endüstri, toplum ve insan etkileşimi bağlamındaki etkilere yansıması sonucunda yenilikçi örgütlerin azlığına işaret ettiği de ayrıca tespit edilmiştir.

Sonuç- Türkiye'nin inovasyon ve rekabetçilik endekslerindeki sıralamasının eğitim sistemindeki mevcut zayıflıkları açıklığa kavuşturmak için bir bütün olarak toplumun içinde daha stratejik ve endüstriyel yaklaşımın başarılarının gerekliliğini teşvik etmeyi mümkün kılarak, etkili yaklaşımlar ve planlanmış eylemlerle uygulanabilmesine endüstri 4.0 uygulamalarının rehberlik edeceği düşünülmektedir.

Anahtar Kelimeler: Dijital Dönüşüm Dinamikleri, Eğitim Sistemi, Endüstri 4.0, İnnovasyon, Yenilikçi Örgüt JEL Codes: I20, L10, P36 


\section{GiRiş}

İletişim ve bilgi teknolojilerinin hızlı gelişimi, bilginin gerçek zamanlı olarak aktarılmasına olanak tanıdığından dünya giderek küresel bir toplum olmaktadır. Bu bağlamda, en gelişmiş ülkelerin, rekabetçi kapasitelerini koruyabilmeleri için endüstriyel sektörün dinamik ve dalgalı bir küresel pazarda güncel kalmasını ve rekabet etmesini teşvik etmek için kendi stratejilerini geliştirmeleri zorunludur. Bu nedenle, endüstrileşmede teknolojik farklılaşma yoluyla rekabet gücünün izlediği yol, daha geniş ve yenilikçi bir araştırma alanı sağladığından, mevcut standartlardaki iş dünyasında endüstri, toplum ve insan etkileşimi ile ilişkimizi değiştirmeye başlayan yeni bir örgütlenme ve sanayi teknolojisi evresi sonucunu ortaya koymaktadır (Taghizadeh ve Keser, 2015).

Günümüzün küresel pazardaki rekabet baskısı, gelişmekte olan ülkelerdeki endüstrilerin varlığına dayatılmaktadır. Bu sanayi şirketleri teknolojik emilim kapasitesine sahiptir ve düşük işletme maliyetleri sunmaktadır. Ülke ekonomisindeki reflekslerle bu dış rekabet etkisini en aza indirgemek için toplumdaki gelecekteki vizyonlarla ulusal stratejilerin geliştirilmesi ve geliştirilmesi ihtiyacına yol açmaktadır. Amaç, yenilikçi ürünler ve hizmetler yoluyla ekonomik açıdan yüksek katma değerli unsurların yaratılması yoluyla uluslararası pazarlarda ulusal sanayi sektörünü desteklemektir. Bu unsurlar, yeni pazarların oluşturulmasında şirket ve kurumların güçlendirilmesine izin verecek, diğer rakiplerden farklılaşarak aynı zamanda kaynaklarını daha verimli kullanarak maliyetlerini en aza indirmektedir. Bu şekilde toplumu istikrarlı bir çevrede korumak ve geliştirmek mümkündür (Yılmaz, 2014).

Küresel rekabet gücü, en gelişmiş ülkeleri, kendi ulusal pazar stratejilerini, içinde de bir yer olduğunu iddia eden yükselen rakiplerin yükselmesiyle gittikçe artan bir pazarda kalmaya devam etmek için yeniden örgütlemişlerdir. Bununla birlikte, günümüzde hala çoğu sanayi kuruluşunda üretim yönetiminin örgütlenmesine Taylor modeli rehberlik etmektedir. Bu durum, üretkenliği en üst düzeye çıkarmak için üretkenliği en üst düzeye çıkarmak amacıyla mevcut kaynakların kullanımı için şirketlerin yüksek verimlilik düzeyine odaklanmasını sağlamaktadır. Yeni rakipler, küresel pazardaki klasik liderliğe giderek daha fazla yakınlaşmakta ve sosyal sınıfın kendini sürdüren ve katkıda bulunan bir sosyal sınıf sürdüren işlerin varlığıyla sosyal barışın sürdürülmesini sağlayan bir alan oluşturmaktadır (Aybars, 2016).

Endüstri 4.0 temasına odaklanan ilgi odağındaki 2013 yıllık dönüm noktasını işaret etmektedir. Endüstri 4.0, merkezi bir üretimden merkezi olmayan bir sisteme temel paradigma kaymasını tanımlayan endüstrinin geliştirilmesi için ortak bir Ulusal Stratejinin tanımlanması amacıyla endüstri liderleri, araştırmacılar, dernekler ve sendikalar tarafından şekillenen 4. Sanayi Devrimi'ne atıfta bulunan bir terim haline gelmiştir. Bu yeni üretken terim olan Endüstri 4.0'e yapılan yatırımın, esnek üretim için inşa edilmiş akıllı üretken sistemler aracılığıyla ekonomik bir destek sağlayabilecek teknolojik bir inovasyon sağlayacağı planlanmaktadır. Tedarik zincirleri ağlarına yerleştirilen, yüksek düzeyde optimize edilmiş proseslere sahip malzemeler ve ürünler, müşteri tarafından talep edilen ihtiyaçlardaki olası değişikliklere hızlı reaksiyon yoluyla yönetileceği ve ürünlerin yaşam döngüsü boyunca hizmette izlenecek ve yetenekli ve uzman bir iş gücü tarafından izleneceği düşünülmektedir (ACATTECH, 2013).

Endüstri 4.0 stratejisi, ilgili tarafların ortak bir vizyona dahil olduğu ve söz konusu olduğu ilk geniş kapsamlı ulusal kapsam kavramının ortaya konmasını tartışmaktadır. Bu, herkesin geleceğe yönelik stratejik bir yolu kabul ettiği ve katıldığı inovasyon alanlarında hedeflerin oluşturulması ve ulaşılacak hedeflerin oluşturulması yoluyla ortak kalkınma arzusunu paylaşılmaktadır. Bunlar, yeni ekonomik araçların tanıtılması ve sosyal diyaloga odaklanan yenilikçi ittifaklara resmi bağııık getirilmesi yoluyla önceliklerin tanımlanmasıyla sonuçlanmaktadır (Açan, 2004).

Ulusal ortak bir probleme yaklaşan bu yeni ortaklaşma biçimi, tüm sosyal ve ekonomik planlarda inovasyon sistemlerinin hızlı ve etkin bir şekilde bütünleşmesini sağlamak için ilgili taraflarca kabul edilmesi gereken bir dizi öneri oluşturmaktadır. $\mathrm{Bu}$, aynı zamanda, inovasyon üretebilen tüm unsurlarla etkileşime giren bir iç öz düzenlemeye de izin vermektedir. Bu inovasyon, üretilen tüm inovasyonların yaygınlaştırılması ve kullanılması için tüm sosyal, ekonomik, politik ve endüstriyel dokularda standartlaştırımış bir iletişim dili olmaktadır (Casper \& Waarden, 2005).

Ulusal düzeyde yetenekli bir dinamik inovasyon sisteminin oluşturulması için şartlar karşılanır karşılanmaz, sürekli bir ekonomik büyümenin sürdürülmesi, herhangi bir ortamda ve rekabet koşullarında pazar koşullandırması, en yeni ve en gelişme potansiyelidir. Bu ulusal stratejinin başarısı için gerekli olan değişiklikler, tüm ilgili tarafların ortak bir yolla koşulsuz kabulünü ve paylaşılmasını gerektirir. Ticarete ilişkin unsurları ekonomik ve sosyal potansiyel ile birleştirerek toplumu stratejiye sokabilecektir. Piyasaların, rekabetin ve yasa koyucunun kendisinin değişkenlerinin mevcudiyeti tarafından zaten şartlandııımış bir ortamda ekonomik sektörlerin parçalanmasına izin verilmeyecek, bu süreç, yaratıcı olarak mevcut farklı unsurlar arasında kullanıcılar ve bilgi ve teknoloji üreticilerinde fikir alışverişi için etkileşimli ve kümülatif hale getirmesini sağlamaktadır (Seyrek, 2015).

Sürdürülebilir kalkınma; herkes için güvenlik ve kalite ortamında kaynakları verimli bir şekilde yönetmek mümkün olmaktadır. Bu gelecekteki intiyaçlarla ilgili olarak, tüm ilgili taraflarla birlikte, ikili ortak bir uluslararası strateji geliştirmektedir. Bu strateji, endüstrinin yeni bir dinamizmini oluşturarak, böylece ekipman üretimi endüstrisi, küresel bir pazarda kendini liderlik içinde konumlandırma yeteneğini koruyabilmektedir. Siber-Fiziksel Sistemlerde Bilgi ve Iletişim 
Teknolojilerinin tutarlı bir entegrasyonu ile aynı zamanda bu ürünler için yeni pazarlar yaratma ve sunma kabiliyeti sağlamaktadır. Bu bağlamda, Endüstri 4.0, sanayide uygulanan bir kontrolün merkezi olmayan bir üretim için merkezi bir şekilde geçişin temel paradigmasının tanımını temsil etmektedir. Bu, son derece esnek ve bireyselleştirilebilir; klasik üretken engeller, yeni teknolojik alanlar ve katma değer süreçlerinin değişmesine yol açan ve iş bölümünün yeniden düzenlenmesini gerektirecek işbirliği biçimlerini ortadan kalkmasını sağlamaktadır (SIEMENS, 2015).

Bu bilgilerden yola çııılarak, araştırmanın amacı; endüstri 4.0 bağlamında dijital dönüşüm dinamiklerinin temelini oluşturan inovasyonel bakış açısının, Türkiye'deki örgüt yapısına etkileri ile Türkiye'nin inovasyon ve rekabetçilik endekslerindeki sıralamasının eğitim sistemindeki eksik noktalarla ilişkisinin incelenmesidir.

\section{LITERATÜR INCELENMESi}

Bu bölümde araştırmanın amacına yönelik ilgili yurtiçi ve yurtdışı çalışmaların literatür incelenmesine yer verilmiştir.

\section{Inovasyon Kavramının Kavramsal Çerçevesi}

Bilgi çağı olarak karakterize edebilen içinde bulunduğumuz 21.yüzyılın en önemli özelliklerini küreselleşme, yenilikçilik ve inovasyon kapsamında; bilimsel ve teknolojik gelişmeler, bilginin gelişmesi ve büyümesi, getirilen değişim ve gelişim olarak listelemek mümkündür. Bununla birlikte, rekabet koşullarının her geçen gün daha da zorlaştığı dünyada, inovasyon, rakiplerine en büyük avantajı sağlamanın anahtarlarından biri haline gelmiştir. Bu nedenle birçok şirket inovasyona ve yenilikçi düşünceye önem vermeye başlamış ve yenilikçi faaliyetler teşvik edici araştırma ve teşvik sistemleri geliştirme yollarına gitmiştir. Ayrıca, Ar-Ge faaliyetlerine yapılan yatırımlar da inovasyonun anahtar bir parçası haline gelmiştir (KAYSO, 2015).

Küreselleşmenin hızlandığı ve sınırları olduğu dünyamızda ana rekabet unsurlarından biri yeniliktir. Artan farkındalık ve takdirin artması, her geçen gün daha da inovasyon alanındaki olanaklarla yüzleşmektedir. Pek çok ülke yeniliği ulusal bir felsefe olarak tanımlar. Rekabetin ana unsurlarından biri haline gelen inovasyon, dünyada ve dünyada inovasyonun önemini artırmaktadır. İnovasyon sadece ürün ve hizmetler olarak değil, aynı zamanda herhangi bir olay, olay ve durumla ilgili getirilen yeni fikirlerin uygulanması ve uygulanması ile ilgili bir süreç olarak ifade edilebilir. Bu nedenle inovasyon kavramına ilişkin açıklamalardan sonra, inovasyon kavramının entelektüel soyutlama kavramından uygulama aşamasına geçerek şekillenen bir kavram olduğu söylenebilir. Zaman içinde rekabet ve zamanla yeni kavram ve fikirlerin ortaya çıkmıştır (Adıgüzel, 2011).

İnovasyonun en yaygın tanımlardan biri; bir iş birimine yeni bir ürün, hizmet veya süreç oluşturmasıdır. Bir diğer tanımda Oslo El Kitabında inovasyonu; bir ürünün (mal veya hizmet) veya sürecin, yeni bir pazarlama yönteminin veya iç uygulamalarda, işyeri organizasyonunda veya dış ilişkilerde yeni veya önemli ölçüde geliştirilmiş yeni bir organizasyonel yöntemin gerçekleştirilmesidir. Drucker'a göre inovasyon; yeni, gelişen beceriler veya faydalanmayı artıran süreç olup, inovasyonun pazara yönlendirilmesi gerektiğini vurgulamıştır (Tsai, 2005).

Genel olarak, inovasyon kelimesi yeni üretim ve sunum yöntemleri kullanarak yeni hizmetler veya ürünler tasarlamak anlamına gelmektedir. Daha önce hiç yapılmamış bir şeyin ortaya çıkarılması durumunda ya da bir sanayi zincirinde ya da işinde bir yerde daha önce yapılmış olan bir şeyin kullanılması, inovasyon olarak değerlendirilebilir. Ayrıca; sanayi endüstriyel faaliyetlerini ürünlerin özelleştirilmesiyle yoğunlaştırmalı ve yüksek karlılıktaki pazar nişlerine yerleştirilmesi gereğidir. Bu, klasik üretken yapının, mevcut ürün ve hizmetlere ilişkin değişkenlerin ve spesifikasyonların giderek daha karmaşık bir şekilde tanıtılması yoluyla değiştirilmesi ihtiyacına benzer sonuçlar doğurmasını neden olmuştur. Bu, üretken sistemleri optimize edebilmek için inovasyon alanında doğrudan yatırım gerektirmektedir. İnovasyonun tanımını ve kavramsal çerçevesini irdeledikten sonra, inovasyonun çeşitlerinden bahsedecek olursak dört çeşit inovasyon sınıflandırılması vardır. Bu sınıflandırmada, ürün ve süreç yenilikleri teknolojik süreci ve ürün yeniliklerini kapsamaktadır (Aybars, 2016):

- Ürün İnovasyonu: Küresel rekabetin artmasıyla birlikte, yoğun uluslararası rekabet, zorlu pazarlar ve hızla değişen teknolojilerin sonucunda, ürün yenilikleri şirketler için daha da önem kazanmaktadır. Ürün inovasyonu, özellikleri veya kullanım amaçlarına göre yeni veya önemli ölçüde geliştirilmiş bir ürünün piyasaya sürülmesidir. Bu ürün hem yeni bir teknoloji hem bilgi hem de mevcut bilgi ve teknolojileri içerebilir. Bir ürünü bir inovasyon olarak adlandırmanın en önemli noktası, mevcut ürünlerden özelliklerine veya kullanım alanlarına göre farklıık göstermesidir. Buna ek olarak, ürün özelliklerinde ve / veya yeni bir kullanım elde etmek için madde ve malzemeler gibi özelliklerde küçük değişiklikler de bir ürün yeniliğidir. Bu durum, ürünün özelliklerinde bir değişiklik içermeyen ve amaçlanan kullanımlar içermeyen tasarım değişikliklerini içermemektedir. Ürün yenilikleri, şirketlerde yeni pazarların örgütsel değişimlerinin ya da sömürülmesinin sonucu olabilmektedir.

Ürün inovasyonu, şirketler için gelir elde etmenin en bariz yollarından biridir. Firmalar, rakiplerin geride kalma riskini göze alamadıkları için yenilenmeli veya tamamen yeni olmalıdır. Bu noktada temel ürün özellikleri radikal 
değişikliklerle geliştirilebilir ve destekleyici faaliyetlerin geliştirilmesi için artan değişiklikler de yapılabilir. Bu, ürünü farklı tekliflerle farklı müşterilere satmayı sağlamaktadır.

- Süreç İnovasyonu: Süreç İnovasyonu, teknik, ekipman ve / veya yazılımlarda önemli değişiklikler içeren yeni veya önemli ölçüde geliştirilmiş üretim veya dağıtım yönteminin uygulanmasıdır. Üretim ya da teslimatın birim maliyetlerini azaltmak, kaliteyi arttırmak ya da yeni ya da geliştirilmiş ürünler üretmek ya da üretmek için proses yenilikleri sağlanabilir. Bir üretim hattındaki yeni otomasyon ekipmanı, yeni üretim yöntemlerinin uygulanmasına bir örnek olabilir. Süreç inovasyonu; sadece üretim ve teslimat iyileştirmelerini içermez ve satın alma, muhasebe, hesaplama ve bakım gibi faaliyetleri de desteklemektedir. Genel olarak, süreç yenilikleri yeni ürünlerin üretimine izin vermektedir. Bu iki yeniliğin bazen birbirinden ayrılamayacağı anlamına gelmektedir.

- Pazarlama inovasyonu: Bu inovasyon, ürün tasarımı veya ambalajında, ürün yerleştirmede, ürün tanıtımında veya fiyatlandırmasında önemli gelişmeler içermektedir. Bu tür yenilikler, müşteri ihtiyaçlarını anlamak, yeni pazarları keşfetmek, mevcut pazarları yeni satışlar yapmak için yeni konumlandırmak ile yakından ilgilidir. Önemli olan, öncelikle pazarlama yöntemini şirket içinde kullanmak ve mevcut ve yeni ürünlere uygulanabilmektir. Yeni yöntem şirketin kendisi tarafından geliştirilebilir veya başka şirketler tarafından da benimsenebilir.

- Örgütsel İnovasyon: Çoğu akademik araştırmada, teknik inovasyonlara odaklanmakta ve bir örgütün etkin çalışması için eşit derecede önemli olan örgütsel inovasyonlara daha az odaklandığı görülmektedir.Kurumsal bir inovasyon, şirketin iş uygulamaları, işyeri organizasyonu veya dış ilişkilerinde yeni bir organizasyonel yöntemin uygulanmasıdır, Bu tür yenilikler, hem buluşu hem de uygulamayı içerir ve kurum tarafından iç uygulamalara, süreçlere ve / veya yapılara yapılan değişiklikler ile ilgili olarak yeni olarak algılanmalıdır. Yenilikler, maliyetleri düşürerek, çalışma koşullarını iyileştirerek, şirketin performansını artırmayı hedeflemeli ve aynı zamanda ilk kez kullanılmalıdır. Bu değişiklikler arasında şirket içi bilgi akışının arttırılması, yeni eğitim ve öğretim sistemleri veya yeni yönetim sistemleri (tedarik zinciri, yeniden yapılandırma vb.) gibi yeni uygulamalar yer almaktadır.Şirkette sorumlulukların ve karar vermenin yeni bir yöntemle dağıtılması işyeri organizasyonunun yeniliğidir. İş̧̧ilerin ekip çalışması faaliyetleri ile karar verme sürecine katkısı, şirketler için kurumsal inovasyonun bir örneği olabilir. Bir şirket dış ilişkiler kullanarak örgütsel değişim yapabilir. İlk defadan bu yana fonksiyonlardan birinin dış kaynak kullanımı, araştırma enstitüleri, tedarikçiler ve / veya müşterileri ile yapılan yeni işbirlikleri bu türden yeniliklerin örnekleri olabilir.

Bir bütün olarak, inovasyon türleri arasındaki ilişki Şekil 1'de verilmiştir.

\section{Şekil 1: İnovasyon Türleri Arasındaki ilişki}

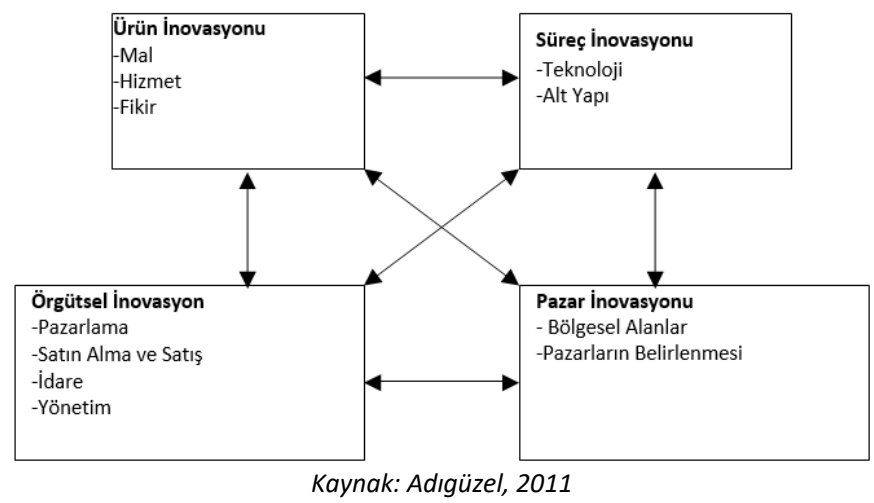

\subsection{Inovasyon Kaynakları}

İnovasyon birçok farklı kaynakla yapılabilmektedir. Bunun dışında, bu kaynaklar; üniversitelerin, kar amacı gütmeyen kuruluşların veya kamu kurumlarının yürüttükleri çeşitli araştırmaların yanı sıra ihtiyaçlarını karşılamak için özel çözümler üreten kullanıcılar gibi bireysel kaynaklardan da olabilir. Şirketler, araştırma fırsatlarının genişliği, kaynak zenginliğinin bolluğu ve kaynaklarını belirli amaçlara yönlendirme yeteneklerinden dolayı en önemli yenilik kaynaklarından biridir. Bu kaynaklara ek olarak, inovasyon için en büyük kaynaklardan biri, bahsedilen beş bileşen arasındaki bağlantıdır (Arpacı, 2009). Bu bağlantı Şekil 2'de gösterilmiştir. 


\section{Şekil 2: İnovasyon Kaynakları Arasındaki ílişki}

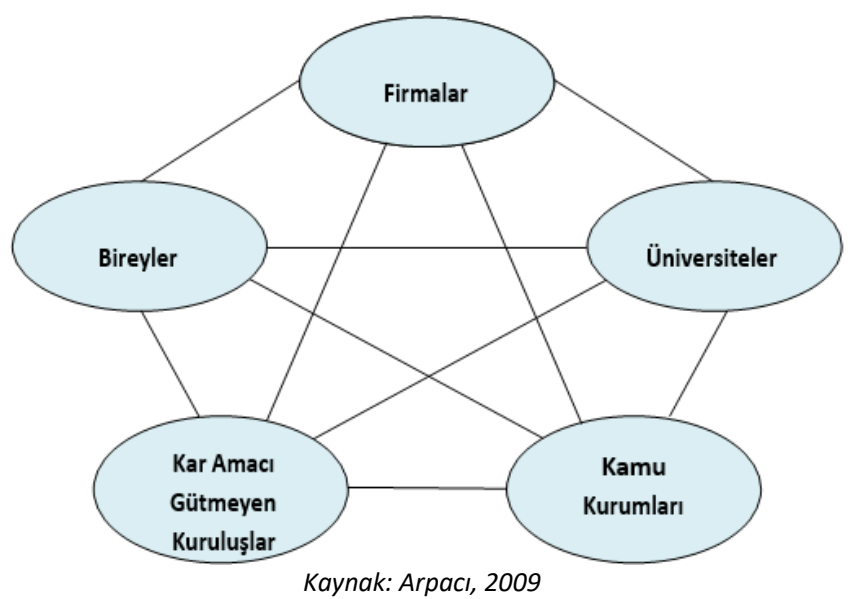

Luecke(2008), altı temel inovasyon kaynağını aşağıdaki şekilde sıralamıştır:

- Yeni Bilgi: Yenilikçi fikirlerin pek çok kaynağı vardır. Radikal yeniliklerin birçoğu yeni bilgilerle üretilmektedir. Yenilikçi ürünlere aktarım için yeni bilgilerin toplanması gerekmektedir ve bu bilgiler ticari olarak güvenilir ürünlere dönüştürülmeli ve geliştirilmelidir.

- Tüketici Düşüncesini Kullanmak: Tüketiciler en önemli fikir, son ürünün zayıf yönleri hakkında en iyi bilgi ve çözülmemiş sorunları tanımlamak için en pratik çözümdür. Tüketiciler bu önlemi dikkate almalı ve tüketicinin ihtiyaçlarını ve isteklerini ortaya çıkarmak için düzenli pazar araştırması yapmalıdır. Daha sonra tüketicinin istediği sonuçlar önem sırasına göre öncelik listesinde sıralanarak işlenmektedir.

- Liderler: Iligili pazarlarda lider bir kullanıcıyı tanımlayarak ve önde gelen kullanıcılarla uyumlu bir ağ geliştirerek ürünleri geliştirmek, taslakta ürünleri şekillendirmek ve iş potansiyellerini değerlendirmesinin mümkün olmasıdır.

- Empatik Tasarım: Empatik tasarım, inovasyon için çaba sarf eden tüketicilerin ve kurumların kendi çevrelerindeki ürün ve hizmetleri nasıl kullandıklarını gözlemleyerek fikir üretme yöntemidir. Benzer durumların ötesine geçmek, rekabet edebilmek ve fark yaratabilmek için, tüketicilerin fark edemedikleri, sorunları gözlemleyebildikleri ve tüketici intiyaçlarını gözlemleyebildikleri problemleri tanımlamak gerekmektedir. Gözlemler, yenilikçi fikirlerin hammaddesini oluşturur ve yenilikçi ürünler yaratmak için kullanılmaktadır.

- Inovasyon Pazarı: İnovasyon piyasası ile inovasyon fikrinden faydalanılması amaçlanmaktadır. Açık inovasyon piyasası, stratejik inovasyonlar, ortak girişimler, ruhsatlandırma ve işletmelerin kendi organizasyonlarının dışındaki yenilikçi etkinliklere erişmelerini sağlamaktadır.

Hippel (1998) ise, inovasyon kaynaklarını dört sınıfa ayırmıştır. Bunlar: kullanıcı bazlı, üretici tabanlı, tedarikçi tabanlı ve rakip tabanlıdır. Kullanıcılar genellikle ihtiyaçların, araştırma ve geliştirmenin, prototip yapımının belirlenmesinde aktif olarak yer alırlar. Ayrıca, genellikle inovasyonun uygulaması ve ticarileştirilmesi ile ilgilenmemektedirler. İnovasyonun uygulanması, ticarileştirilmesi ve yayılmasında üreticiler önemli bir rol oynamaktadır. Başka bir deyişle, inovasyonun ekonomik yönü ile ilgilenmektedirler. Bir inovatör satmak istediklerine göre bir talep artışı yarattığında, tedarikçiler kullanımlarını veya satışlarını tahmin etmeyen bir inovasyon geliştirebilmektedir. Yenilik, sonuçta ortaya çıkan bilgi yarışmasından da kaynaklanabilir. Drucker (1998) de, inovasyon kaynaklarını yedi sınıfa ayırmıştır. Bunlar; beklenmedik gelişmeler, çatışmalar, süreç ihtiyaçları, endüstri ve piyasa yapısı değişimi, demografik değişim, algı değişikliği ve yeni bilgidir. Bu kaynakların ilk dördü iç ve endüstri ile ilgilidir, diğerleri ise şirket dışındaki sosyal ve entelektüel çevrelerle ilgilidir. Bunlar (Hobbikoğlu,2009):

- Beklenmeyen Gelişmeler: Beklenmedik başarı, başarısızık veya harici bir olay, benzersiz bir fırsatın işareti olabilir. Örneğin, bankalar 1930'larda IBM'in faturaları satmak için geliştirdiği, kütüphanelerin çok dikkat çektiği hesap makinesini talep etmemesidir.

- Çatışma: Beklenen ve beklenenler arasındaki çelişki, yenilikçi bir fırsat oluşturabilmektedir. Örneğin, 1950'lerde, taksilerin hızı arttıkça ve yakıt tüketimi azalsa da, gemi inşasının iş hacmindeki düşüş operasyonel sorunların anlaşılmasına neden olmuştur. 
- Süreç Gereksinimi: Bir süreçte sabit olmayan zayıf bir bağlantı, yenilik için bir fırsat yaratabilir. Örneğin, gazetelerin reklam alarak hayatta kalamayacağı görülmektedir.

- Endüstri ve Piyasa Yapısı Değişimi: Endüstri ve piyasa yapısındaki değişiklikler ürün, hizmet ve iş yaklaşımlarında bir dizi inovasyon fırsatı oluşturmaktadır.

- Demografik Değişim: Etki, yaş, işsizlik, eğitim ve gelir düzeylerindeki değişimlere bağlı olarak bir inovasyon fırsatı ortaya çıkabilir. Örneğin, aileleriyle birlikte tatil yapmaktan memnun olmayan gençler için farklı alternatiflerle yaz kamplarının ortaya çıkmasıdır.

- Algıdaki Değişim: Belirli bir toplumun genel görüşleri, tutumları ve inançları değiştiğinde yenilik fırsatları ortaya çıkabilir. Örneğin, sağlık sorunlarının son evinde kullanılabilecek spor ekipmanlarının geliştirilmesidir.

- Yeni Bilgi: Bilimsel, teknik veya sosyal bilgilerdeki değişim yeni ürünler ve yeni pazar yenilikleri için fırsatlar oluşturmaktadır. Bu tür yenilikler, tek bir bilgi türü yerine birden fazla bilginin kullanılmasını gerektirebilir.

\subsection{Endüstride Yeni Yaklaşım Endüstri 4.0 ve İnovasyon}

Dördüncü sanayi devrimi, önceki endüstriyel hareketlerden çok farklı yaklaşımlara sahiptir. Mevcut sanayi altyapısını yapay zeka ve makineler arası iletişim teknolojileri ile donatmayı amaçlayan bu devrimci süreç, akıllı emekten soyutlanmış yeni bir üretim stratejisini hedeflemektedir. Bu bağlamda, Endüstri 4.0'ın temel hedefleri ekonomik büyüme, istihdam ve sosyal istikrar, kalıcı değer üretimi, iş güvenliği, daha yüksek verimlilik ve yüksek bir yaşam standardıdır. Bu kavram ilk olarak 2011 yılında Hannover Fuarı'nda, Endüstri 4.0'ın, bilgi çağının başladığı 1970'lere uzanan ana teknolojik altyapısıyla kullanılmıştır. Almanya'nın konuyla ilgili çalışması, 2012'de Sanayi 4.0 Çalışma Grubu'nun kurulmasıyla başlamış ve 2013'te çalışma grubunun nihai raporunda şekillenmiş ve bu endüstriyel dönüşümün başarılı olabilmesi için sekiz kilit meselenin yerine getirilmesi gerektiğini belirtmiştir. Bu makalede ele alınan başlıklar arasında referans mimarilerin tanımlanması ve standardizasyonu, karmaşık sistemlerin yönetimi, endüstriye kapsamlı ve yüksek hızlı iletişim altyapısının sağlanması, güvenlik ve güvenlik, iş organizasyonu ve tasarımı, eğitimin devamlılı̆ı ve profesyonelliği yer almaktadır. Endüstri 4.0'ı oluşturan ve gelecek yüzyıla rehberlik etmesi beklenen kavramlar arasında 3D Yazıcılar, Nesnelerin İnterneti, Akıllı Kumaşlar, Siber-Fiziksel Sistemler, Büyük Veri, Özerk Robotlar, Simülasyon, Sistem Entegrasyonu, Bulut Bilişim Sistemi ve Artırılmış Gerçeklik yer almaktadır (Çeliktaş ve diğerleri, 2015).

Dördüncü sanayi devrimi, nihai tüketiciye kadar değer zincirine bağlı tüm bileşenlerin gerçek zamanlı olarak birbiriyle bütünleşmesini amaçlamaktadır. İnsanların, nesnelerin ve sistemlerin bağlanmasını içeren bu süreç, şirketlerin hem kendi içinde hem de kendi aralarında dinamik bir ilişki geliştirmelerine ve gerçek zamanlı optimizasyon yoluyla daha yüksek katma değerli ürünler üretmelerine olanak sağlamaktadır. Üretim ağının tüm unsurları birbirleriyle internet teknolojilerini kullanarak iletişim kurar ve gerçek bir dünya bilgi sistemi haline gelmektedir. Bu teknolojik altyapının kullanılması, imalat sektörünü daha verimli hale getirmekte, sistemleri kalite ve esnekliği arttırmak için bütünleştirmekte ve veri analizi programlarını kullanarak rekabet ortamında avantaj sağlamaktadır. Endüstri 4.0'ın uygulanmasından sonra ortaya çıkacak değişiklikler genel olarak aşağıdaki gibi sıralanmaktadır (Tağızade ve Keser, 2015):

- Internet ve siber fiziksel cisim sistemleri ile daha karmaşık ve akıllı ürünlerin yaratılması,

- Özel üretim, seri üretim yerine bireyin iradesine bağlıdır.

- Üretim tesisleri ve ürünleri ile gerçek zamanlı veri ve bilgi alışverişi,

- Hammadde ve kaynak tüketimini optimize ederek, verimliliği artırmak ve alternatif enerji kaynaklarını kullanmak,

- Akıllı makineler / robotların üretim süreçlerinin artan verimliliği,

- Imalat sektöründe işgücü ihtiyacında azalma,

- Üretimdeki hata payının minimuma indirilmesi,

- İş sağlığı ve güvenliğinin geliştirilmesi,

- Esnek çalışma saatleri,

- 3D yazıcıların kullanımı ile ev ortamında basit üretim süreçleri ile bireysel ihtiyaçların gerçekleştirilmesi,

- Endüstri 4.0 ile uyumlu şirketlerin küresel pazar payı,

- Üretim ve tüketim, sanal dünya ile daha iç içe geçmektedir.

Yeni sanayi üretim teknolojilerine geçtikten sonra, verimliliğin 5 yıl içinde \%18 oranında artması beklenmektedir. Bunu gerçekleştirmek için, en önemli şartlardan biri olan iletişim teknolojisinin gelişmesinin kademeli bir artışla devam edeceği ve 2020 'lerde internette bağlı olarak yaklaşık 50 milyar cihazın çalışacağı tahmin edilmektedir. Tahminlere göre, sanayi satışları ilk sırada yılda \% 2-3 oranında artacak. Almanya'nın Endüstri 4.0'ın öncüsü olarak dikkate alındığında, yıllık 30 milyar EURO ciro ve Avrupa'da 100 milyar EURO'luk bir artış yaşanacağı tahmin edilmektedir (Ege, 2014; Şimşek, 2016). 
Sanayi devriminin bu avantajlarına ek olarak, uygulanabilirliği ve sonuçları konusunda bazı tereddütler dile getirilmiştir. Bunun nedeni, işgücü piyasasının daralması ve işsizlik oranlarının küresel ölçekte artmasıdır. Her sanayi devriminin, kendi üretim ilişkisine bağlı olarak yeni istihdam pazarları yaratması, daha önceki sanayi devrimlerinin başlangıcında benzer olsa da, bu konuda daha fazla çalışma gerektirir. Ancak genel olarak sanayi devriminin mavi yakalı işçilerin sayısını azaltacağı ve nitelikli işgücü talebini artıracağı kabul edilmektedir. Endüstri 4.0 stratejisi, ilgili tarafların ortak bir vizyona dahil olduğu ve söz konusu olduğu ilk geniş kapsamlı ulusal kapsam kavramının ortaya konmasını tartışmaktadır. Bu, herkesin geleceğe yönelik stratejik bir yolu kabul ettiği ve katıldığı inovasyon alanlarında hedeflerin oluşturulması ve ulaşılacak hedeflerin oluşturulması yoluyla ortak kalkınma arzusunu paylaşılmaktadır. Bunlar, yeni ekonomik araçların tanıtılması ve sosyal diyaloga odaklanan yenilikçi ittifaklara resmi bağlılık getirilmesi yoluyla önceliklerin tanımlanmasıyla sonuçlanmaktadır (Aybars, 2016). Ulusal ortak bir probleme yaklaşan bu yeni ortaklaşma biçimi, tüm sosyal ve ekonomik planlarda inovasyon sistemlerinin hızlı ve etkin bir şekilde bütünleşmesini sağlamak için ilgili taraflarca kabul edilmesi gereken bir dizi öneri oluşturmaktı. Bu, aynı zamanda, inovasyon üretebilen tüm unsurlarla etkileşime giren bir iç öz düzenlemeye de izin verecektir. Bu inovasyon, üretilen tüm inovasyonların yaygınlaştırılması ve kullanılması için tüm sosyal, ekonomik, politik ve endüstriyel dokularda standartlaştırılmış bir iletişim dili olmaktadır (Adıgüzel, 2011).

Ulusal düzeyde yetenekli bir dinamik inovasyon sisteminin oluşturulması için şartlar karşılanır karşılanmaz, sürekli bir ekonomik büyümenin sürdürülmesi, herhangi bir ortamda ve rekabet koşullarında pazar koşullandırması, en yeni ve en gelişme potansiyelidir. Bu ulusal stratejinin başarısı için gerekli olan değişiklikler, tüm ilgili tarafların ortak bir yolla koşulsuz kabulünü ve paylaşımasını gerektirir. Ticarete ilişkin unsurları ekonomik ve sosyal potansiyel ile birleştirerek toplumu stratejiye sokabilecektir. Piyasaların, rekabetin ve yasa koyucunun kendisinin değişkenlerinin mevcudiyeti tarafından zaten şartlandırılmış bir ortamda ekonomik sektörlerin parçalanmasına izin verilmeyecek, bu süreç, yaratıcı olarak mevcut farklı unsurlar arasında kullanıcılar ve bilgi ve teknoloji üreticilerinde fikir alışverişi için etkileşimli ve kümülatif hale getirilmelidir (Ersoy, 2016).

Şekil 3: Ülkelerin İnovasyon Stratejisi Hedefleri

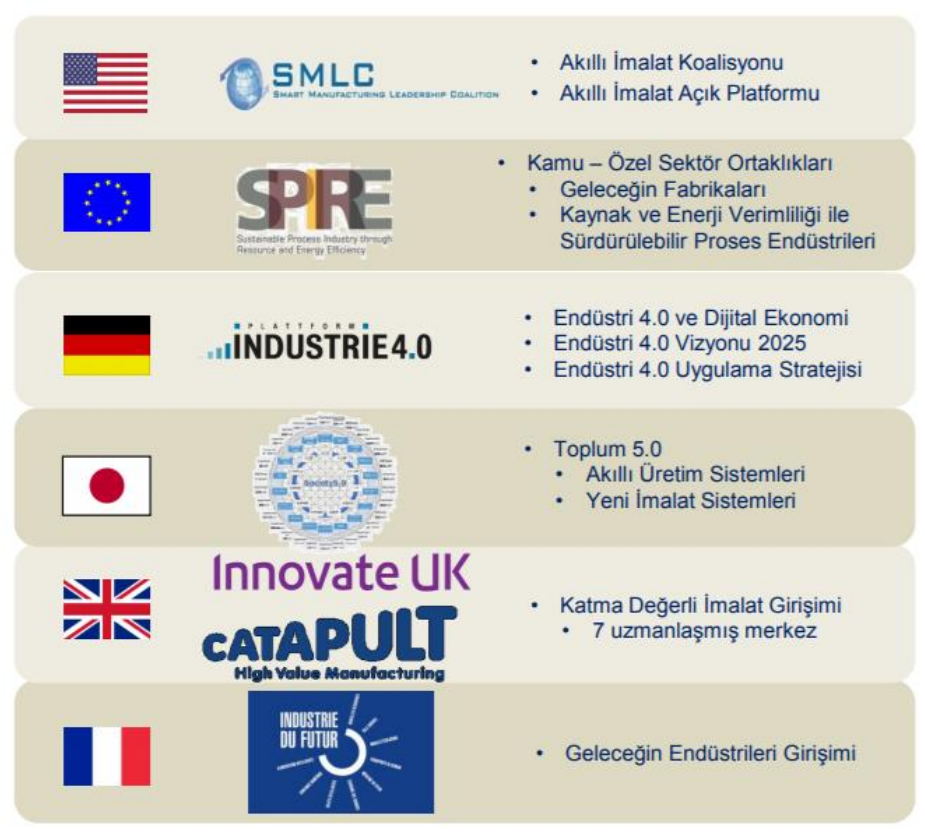

Kaynak: TÜBіTAK, 2016

Ortak bilgilerin paylaşımasındaki bu yaklaşım, tüm ilgili taraflara hedef pazarlar olarak önerilen sektörler ile aynı şekilde performans göstermesi için bir bilgi alışverişinin ve değişimin analizine olanak sağlayacaktır. Bu, ulusal endüstriyel dokumanın sürekli korunmasında teknolojik bir gelişmeye ve bunun sonucunda sosyal refahın sürdürülmesine olanak sağlamaktadır. Toplumdaki uygulama kapasitesi ve yeteneklerin paylaşılan sinerjisinin uyarılması, elde edilen performanstaki farkı oluşturabilecektir. Bu, ulusal olarak devletin hayatta kalmasını veya uluslararası statüsünü liderlik olarak sürdürmesini etkilemekten sorumlu olacağı düşünülmektedir (Schilling, 2005). 


\subsection{Ulusal İnovasyon Stratejisi ve Türkiye'deki Ulusal İnovasyon Stratejisi}

Illgili literatürde ulusal inovasyon sistemini; Freeman (1987), "yeni teknolojilerin ve faaliyetlerin benimsenmesine, kazanılmasına, dönüştürülmesine ve yayınlanmasına izin veren özel ve kamu sektörü kurumlarının ağ yapısı" olarak tanımlarken; Nelson (1993) ise, "ulusal firmaların yenilikçi performansını belirleyen bir dizi kurumsal ilişki" olarak tanımlamıştır. Freeman'a göre, ulusal inovasyon sistemi kavramını ilk Bengt-Ake Lundval kullanmıştır. Ancak, Lundval'in belirttiği gibi, bu fikir 1841 'de yayımlanan "Ulusal Ekonomi Politik Sistemi" başlıklı Friedrich List'e uzanmaktadır Büyük Britanya İmparatorluğu'nun üstünlüğünün, dünya pazarlarındaki teknolojinin egemenliğinden kaynaklandığını düşünen (1789-1846) liste, Almanya'nın da yeni teknolojileri öğrenip emmesi, ekonomik faaliyet alanlarına yayılması ve bu teknolojileri sağlam bir temele, sanayiye, devlet makine ve üniversitelerine yerleşmeyi mümkün kılacak bir eğitim sistemi ile yüksek düzeyde yeniden üretme yeteneğidir. OECD tanımına göre, bir ülkede inovasyon ve teknoloji yayılımının hızını ve yönünü etkileyen piyasa ve piyasa dışı kuruluşlar ulusal inovasyon sistemini oluşturmaktadır. Bu sistemin babası olarak kabul edilen Lundval, ulusal inovasyon kavramını "ekonomik yapı ve kurumsal oluşumların yanı sıra araştırma ve keşiflerin öğrenimini etkileyen tüm yönler ve tüm yönler" olarak tanımlamaktadır. Patel ve Pavitt (1994)'e göre ise; ulusal kurumlar, bir ülkede teknolojik bir öğrenmenin hızını ve yönünü ya da bunların hacmi ve bileşimini belirleyen ulusal kurumların değişim oluşturan faaliyetlerin teşvik ve yetenekleridir (Arıkan, 2003).

Ulusal inovasyon sistemi kavramı, teknolojik performansı geliştiren firmalar arasındaki bağlantıların anlaşılmasının önemini vurgulayan ön eke dayanmaktadır. Yenilik ve teknik ilerleme, farklı türde bilgi yayan, yayan ya da üreten aktörler arasındaki karmaşık bağlantıların sonucu olarak ortaya çıkmaktadır. Yenilikçi performans, aktörlerin birbirine nasıl bağlı olduğuna bağlıdır. Bu aktörler öncelikle özel girişimciler, üniversiteler, kamu araştırma kuruluşları ve içerdikleri kişilerdir. Buna göre; aslında, bu kavram için kabul edilen tek bir tanım yoktur (OECD,2012).

Şekil 4: Küresel Üretim Ağları

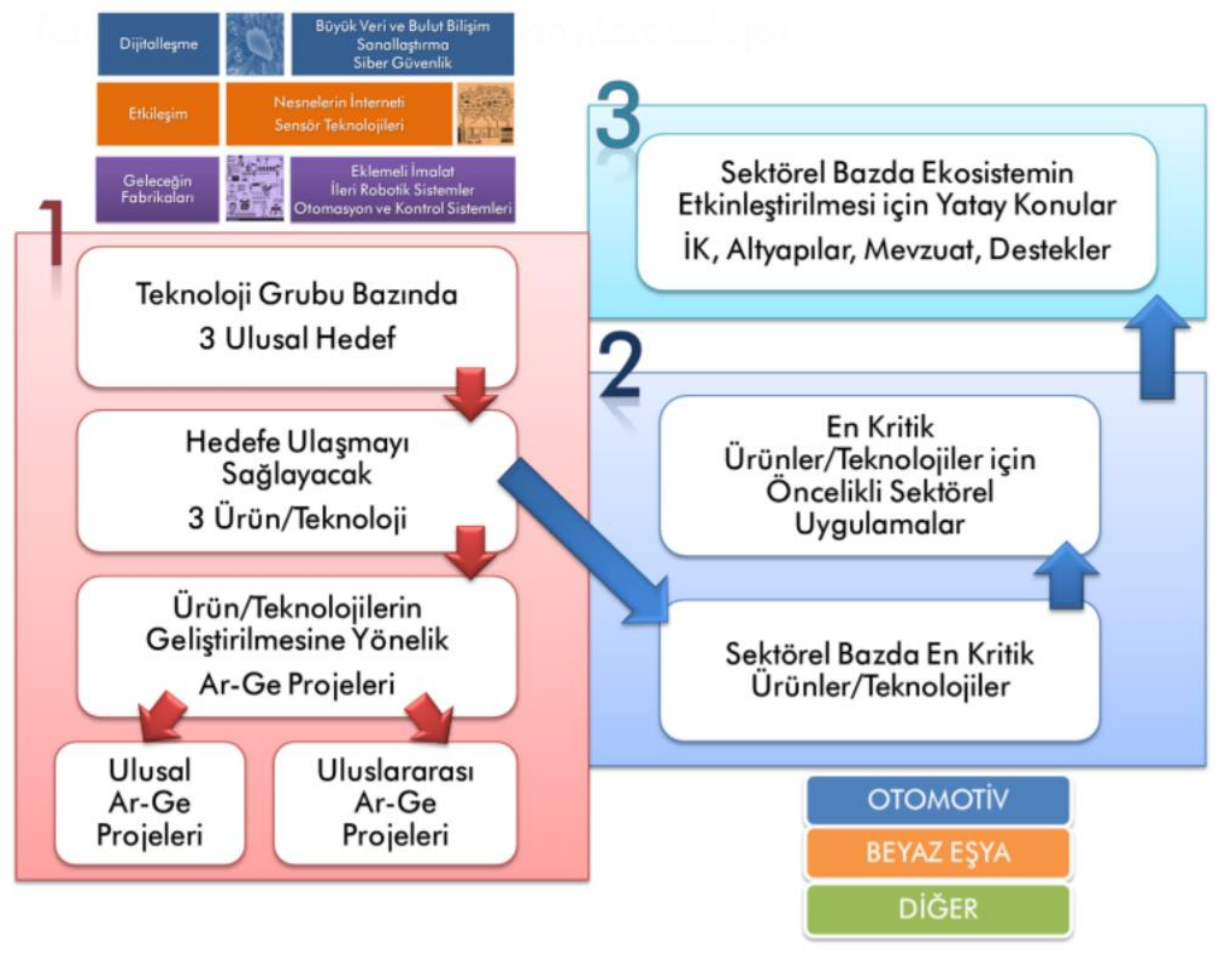

Kaynak: TÜBITAK, 2016

Küresel rekabet gücü, en gelişmiş ülkeleri, kendi ulusal pazar stratejilerini, içinde de bir yer olduğunu iddia eden yükselen rakiplerin yükselmesiyle gittikçe uçucu bir pazarda kalmaya devam etmek için yeniden örgütlemişlerdir. Bununla birlikte, günümüzde hala çoğu sanayi kuruluşunda üretim yönetiminin örgütlenmesine Taylor modeli rehberlik etmektedir. Bu durum, üretkenliği en üst düzeye çıkarmak için üretkenliği en üst düzeye çıkarmak amacıyla mevcut kaynakların kullanımı için şirketlerin yüksek verimlilik düzeyine odaklanmasını sağlamaktadır. Yeni rakipler, küresel pazardaki klasik liderliğe giderek daha fazla yakınlaşmakta ve sosyal sınıfın kendini sürdüren ve katkıda bulunan bir sosyal sınıf sürdüren işlerin varlığıyla sosyal barışın sürdürülmesini sağlayan bir alan oluşturmaktadır. Ayrıca, bu sayede yerli üretim maliyetlerini 
azaltmayı ve üretkenlik düzeyini yükseltmeyi amaçlayan, zayıf gelişmiş ekonomilerdeki en gelişmiş teknolojik ulusların endüstriyel dokusunun bir kısmının göçü ve yer değiştirmesi, son yıllarda küresel düzeyde rekabet endüstrisinin genişlemesine ve yükselmesine olanak sağlamaktadır. Bu şirketler, küresel pazardaki katma değerin uygulanmasının bir parçası olarak kendileri için talepte bulunmak için dünya seviyesinde rekabet gücünü değiştirmede aktif bir rol oynamışlardır. Bu endüstriyel ürünlerin üretimi yoluyla elde edilen bilgi ve beceriler, yabancı teknolojinin en endüstriyel ülkelerden transferi ile mümkün olmuştur. Sonuç olarak, oluşturulan refahtan kaynaklanan sosyal değişimlerle birlikte üretken süreçler geliştirerek erişilebilir içsel bilgi kapasitelerinin inşası ve gelişmesini sağlamıştır. Bu refah, yaratılan istihdam nedeniyle orta sınıf bir tüketici oluşturmakta ve geliştirmektedir. Bu bağlamda, diğer kilit faktörlerle paralel olarak ekonomik gelişme, bilgi ve iletişim teknolojilerinin geliştirilmesinden bu yana küreselleşmenin hız kazandığı bir motor haline gelmiştir. Bu teknolojiler, finansal ve üretken alt yapıların tahsisi ve dağıtımı yoluyla endüstriyel teknoloji transferi sürecini hızlandırmaktadır (Satı- Ecevit, 2013).

Türkiye'de ulusal inovasyon faaliyetlerinin ilk adımı 1963'te Türkiye Bilimsel ve Teknik Araştırma (TÜBiTAK) kurulmasıyla başlamıştır. 1983 yılında TÜBITAK, hedefleri arasında Ar-Ge faaliyetlerini artırmayı ve teknolojinin öncelikli alanlarını tanımlamayı amaçlamıştır. Yine 1983'te kurulan "Bilim ve Teknoloji Yüksek Kurulu" (BTYK), ulusal inovasyon stratejilerini şekillendirmek için önemli girişimlerden biri olmuştur. 1993 yılında oluşturulan "Türk Bilim ve Teknoloji Politikası: 19932003" belgenin amacı "sistemli tüm kurumların ve diğer mekanizmaların sistematik bir uyum içinde bilimsel ve teknolojik Ar-Ge faaliyetlerini geliştirmesini ve tüm faaliyetlerin sonuçlarını dönüştürmek için ulusal bir inovasyon sistemi kurmak" olmuştur. Ağustos 1997'de, BTYK “1996-1998 Yılları için Bilim ve Teknoloji Politikası Gündemi” başlıklı raporu onaylamış olup, raporda ulusal bilim ve teknoloji politikasının ana temalarından biri olan ulusal bir inovasyon sistemi oluşturmak için gerekli hazırlıklar yer almıştır. BTYK'nın bu raporu, inovasyon kavramı etrafında şekillenmiştir. Raporda bölgesel inovasyon sistemleri üzerine araştırmalar yapmak, inovasyon kavramı, teknoloji yönetimi, inovasyon ve kalite yönetimi tekniklerinin yaygınlaştııılması, inovasyon geliştirme faaliyetlerinin hızlandırılması ve yakın zamana kadar KOBi'lerin inovasyon geliştirme faaliyetlerini destekleme alanı hakkında farkındalık oluşturulması yer almıştır. Aralık 2000'de ise; Bilim ve Teknoloji Yüksek Kurulu (BTYK) toplantısında, 1993 yılında gerçekleştirilen en son bilimsel ve teknolojik politika çalışmaları ile TÜBiTAK, 20 yıllık bir dönemi kapsayan yeni bilim ve teknoloji politikalarının belirlenmesi için, BTYK kararına göre yapılacak çalışmanın ana ekseni olan Türkiye, Teknoloji Öngörüsü çalışmasının ilk kez ulusal düzeyde gerçekleştirilmesine karar vermiştir. 2001 yılının Aralık ayında, BTYK'nın bu hazırıkları sunmasıyla operasyon, bir yıl önce operasyon, Türkiye'nin bilimi ve teknoloji sistemi "Teknolojik Yetenekler", "Araştırmacı Envanteri" ve "Ulusal” ile ilgili objektif veriler ile bağlantılı olarak "Teknoloji Öngörüsü" nü kabul etmiştir. Vizyon 2023 "Proje," Altyapı Altyapısı "başlıklı dört alt projeden oluşmaktadır. Ana sebep olarak 'Vizyon 2023' olarak adlandırılan proje, bu süreçte Türkiye Cumhuriyeti'nin 100. yıldönümüne layık bir yapı sağlaması hedeflenmiştir. Bu nedenle; teknoloji Öngörü Paneli'nde oluşturulan vizyonun gerçekleştirilmesi için dört sosyoekonomik hedefin gerçekleştirilmesi gerektiğine karar verilmiştir. Endüstriyel üretim alanında bu hedefler, Türkiye'nin rekabet avantajı, kazanılması uluslararası ticaretin önemli bir bölümünü yer almış olup, insan yaşam kalitesini yükseltmek; sürdürülebilirliği sağlayarak gelişme; bilgi ve iletişim teknolojileri altyapısını güçlendirmek olarak dile getirilmiştir (Şengün, 2009).

\subsection{Eğitimde İnovasyon}

İnsan hayatındaki en önemli olaylardan biri olan eğitim, doğumla başlayan ve ölüme giden kesintisiz bir süreçtir. Eğitim genellikle farklı biçimlerde farklı ifadeler olarak tanımlanmaktadır. Kuşkusuz, eğitimcilerin farklı amaçları bu farklılaşmalarda rol oynamaktadır. Kullanılan tanımlardan biri "bireyin içinde yaşadığı toplumdaki yetenek, tutum ve diğer davranış biçimlerini geliştirdiği süreçlerin toplamı" olarak tanımlanmıştır, Durkheim (1956), "genç neslin toplumsallaşma yöntemi olarak sosyalleşmesi" tanımını getirmiştir. Tyler (1950) ise, "bireylerin davranışlarını değiştirme süreci" terimini eğitim için tanımlar Tyler'ın tanımına yakın bir tanım Ertürk tarafından da yapılmıştır. Ertürk (1984)'e göre; eğitim, “bireyin davranışlarına kendi deneyimleri aracılığıyla değişim getirme ve bilinçli olarak değişme süreci" dir. Buradan yola çıkarak, eğitimcilere göre eğitim "bilgi, eğitim ve yeteneklerin geliştirilmesi ve sürekli bir dizi faaliyetin geliştirilmesi için bir dizi sürekli etkinlik" olarak tanımlanırken, ekonomistler ve politikacılar için ise "insan sermayesine yatırım" olarak tanımlanmıştır (Arslan, 2004).

İlgili literatür incelendiğinde, yapılandırılmamış eğitimin kökenlerinin geçmişe kadar uzandığı görülmektedir. Yapılandırılmış eğitim ise, insanlık tarihi göz önüne alındığında, sadece iki asırlık bir geçmişi olan nispeten yeni bir kurumdur. Eğitimin bir metodun gelişimi üzerinde doğrudan bir etkisi olduğunu kabul etmek, sadece birkaç on yıl öncesine dayanan bir konu olarak ortaya çıkmıştır. Hükümetler ve uluslararası örgütler eğitim ilerlemesini iyileştirmek için 50 yıldan fazla bir süredir çaba göstermektedir. Bu çabalar, gelişmiş ülkelerde temel eğitimde ciddi bir rekabet haline gelmiştir. BM, UNESCO, UNICEF, ILO ve Dünya Bankası eğitimi en temel insan hakkı ve gelişme aracı olarak yer almaktadır (Patrinos ve Psacharapoulos, 2011).

Geçtiğimiz on yılda, dünya çapında eğitim; sosyal, ekonomik, sivil ve kültürel açıdan daha merkezi olma açısından giderek daha geniş bir öğrenci nüfusu olan eğitim reformu, ülkelerin siyasi ve ekonomik beklentilerini oluşturmaktadır. OECD ülkeleri için eğitim; verimliliği ve rekabeti artıran, insanların beklentilerini karşılayan ve sosyal yakınlığı güçlü tutan bir unsur 
olarak görülmektedir. Gelişmekte olan ülkelerde, başarılı sağlık sonuçlarının elde edilmesi, nüfus istikrarının ve istikrarlı yönetimin sağlanması ve ekonomik büyümenin sağlanması için eğitime ihtiyaç vardır. Bu kapsamda; küresel değişim eğitimi daha da dikkate değer kılmaktadır. Eğitim zengin ülkelerde refahı sürdürmek için bir faktör olarak kabul edilirken, kalkınma düşük seviyeli bir servet seviyesine sahip olan ülkelerde itici güç olarak görülmektedir. Ekonomik rekabet ve sosyal bozulma arttıkça, eğitim sistemlerinin mevcut performansının iyileştirilmesi ve yeni taleplere cevap verilmesi beklentileri de artırmaktadır. Bu nedenle; bireylerin refahı, ülkenin sosyal bileşenlerinin entegrasyonu, ekonominin dayanıklılığı ve uzun vadeli ulusal güvenlik, okulların ve eğitimin verimliliğine dayanmaktadır (Bentley, 2008).

Eğitimde inovasyon kavramı, farklı öğretim sistemlerinin yıllar içinde test edildiği düşünüldüğünde, eğitim tarihi ile başlayan bir gerçek olduğunu söylemek yanlış değildir. Ekonomistler, inovasyonun ülkeler için ekonomik ve sosyal gelişmenin anahtarı olarak ulusal ekonomilerin kalkınmasını ve sürdürülebilirliğini sağlamak için eğitimin yer aldığı büyük ölçekli yenilikçi programlara yatırım yapmanın önemini sürekli olarak vurgulamaktadır. İnovasyon, eğitim sektöründe önemli bir ilgi alanı oluşturmaktadır. Ancak, başarılı inovasyon insan yaratıcılığı, bilgisi, becerileri ve yetenekleri ile beslenerek gelişmekte ve bunu geniş perspektifte onları sağlayan eğitimdir. Eğitim ve öğrenmede inovasyona yol açan faktörler aşağıdaki gibi sıralanabilir (Looney, 2009):

- Başarı düzeyini yükseltmek ve sonuçların tüm öğrenciler için adil olmasını sağlamak için sosyal ve ekonomik baskı,

- Iş, sosyal ve aile yaşamında değişim,

- Hızla gelişen teknolojiler,

- Öğrencileri motivasyonudur.

Tüm dünyadaki reformcular, çocuklarının mevcut eğitiminde yeni yeniliklere ihtiyaç duyduklarını söylemektedir. Çünkü yoğun küresel ekonomi rekabet açısından değerlendirildiğinde ve bilgi toplumlarının teknolojik talepleri arttığında, endüstriyel ve hatta tarımsal sosyoekonomik okul modelleri, tüm öğrencilerin başarıya ulaşması için fırsat vermekten uzaktır. Ek olarak, inovasyon ihtiyacının bilinci yaygın olarak, ekonomik rekabet gücünü güçlendirmek isteyen politikacılar, küresel ekonomide başarılı olmak için eğitim ve becerileri geliştirmek amacıyla yenilikçi eğitim sistemlerine daha fazla önem vermektedir (Lubienski, 2009). Gelişmiş ekonomik büyümeyi isteyen ülkelerin çoğunun ulusal eğitim politikaları, aşağıdaki temalar etrafında sıralanmıştır (Bentley, 2008):

- Özellikle aritmetik ve okuryazarlık alanlarında başarı düzeyini geliştirmek için standartlara dayalı stratejiler,

- Kilit performans göstergelerine dayalı raporlama, değerlendirme ve hesap verebilirlik çerçeveleri,

- Okul binalarının modernizasyonu, bilgi iletişim teknolojilerinin altyapısı ve ağ altyapısı dahil yeni altyapı,

- Sınıfların azaltılması ve yeni öğretmenlerin eğitimi,

- Yüksek performanslı eğitim liderlerinin belirlenmesi, eğitimi ve ödüllendirilmesi,

- Yükseköğretimi genişleterek, yeni okul çalışma yolları ve daha yüksek mesleki nitelikler oluşturarak, zorunlu eğitimden sonra katılımın arttırılması,

- Eğitim işgücü; esneklik, profesyonel gelişim, profesyonel uzmanlık ve asistan personelin rollerinin belirlenmesi, performans yönetimi konularına önem verecek şekilde şekillendirilmesi,

- Gençler arasında sivil dayanışma ve vatandaşlık geliştirmek,

- Kentsel ve kırsal alanlardaki özel ve mahrum sosyal gruplar ve son gruplar arasındaki düşük performansla mücadele edilmesidir.

Bütün dünyada, özellikle II. Dünya Savaşı'ndan sonra yaygınlaşan eğitimdeki değişimler ve gelişmeler Türkiye'de de kendini göstermiştir. Cumhuriyet Dönemi'nde 3 Mart 1924'te kabul edilen ilk eğitim reformu olarak kabul edilen Tevhid-i Tedrisat Kanunu'nun sürekli gelişimi söz konusu olmuştur. Özellikle 1980'lerden beri toplumun gelişmesi, açıklığın dışarıdaki dünyaya ivme kazandırması, eğitimde yeniliği hızlandırmıştır. Türkiye, 2004 yılında AB katılım müzakereleri için Kopenhag kriterlerinin imzalanmasıyla 2005 yılında açılmıştır. Bu başlıkların 26'sı eğitim ve kültür unvanı olup, eğitim, öğretim, gençlik ve kültür odaklıdır. $A B$ entegrasyon süreci için, eğitimde yenilik de bir zorunluluk haline gelmiştir. Eğitim sisteminin sorunlarını çözmeyi, daha kaliteli bir eğitim sistemi kurmayı ve Dünya Bankası (DB), Avrupa Birliği gibi uluslararası kuruluşların finansal ve insani desteğiyle gerçekleştirilen eğitim reformlarıyla öğrencilerin performanslarını iyileştirmeyi hedeflemektedir (Çelik, 2012).

Türkiye'deki eğitim faaliyetleri, Milli Eğitim Bakanlığı tarafından 1739 sayılı Milli Eğitim Temel Kanunu kapsamında yürütülmektedir. Okul öncesi eğitim, ilköğretim, genel ortaöğretim ve meslek yüksekokulu ve yükseköğrenimden oluşan eğitim sistemi; merkezi ve taşra teşkilatı olarak iki ana yapıya sahiptir ve tamamen merkezi bir yönetim sistemine sahiptir. Eğitim, merkezden tamamen yönetildiği için, yenilikçi uygulamalar okulda ya da bölgesel olarak daha az yaygındır. Müfredat yenilikleri, öğrencilere nasıl anlatacaklarını ve onlara ne söyleyeceklerini anlatma üzerine odaklanmıştır ve okulların kararı ve uygulanması oldukça sınılıdır. Eleştirel düşünme, problem çözme, karar verme, iletişim, işbirliği, bilgi okuryazarlığı, araştırma ve soruşturma, medya okuryazarlığı, dijital vatandaşlık, operasyonları ve kavramları, esneklik ve uyum, girişimcilik 
ve öz-yönelim, 21. yüzyıl becerileri ve yeterlilikler gibi verimlilik ve / ya da liderlik ve sorumluluk gibi kavramlar müfredata, yönetmeliklere ve kurallara dahil edilir, bu konuda öğretmen eğitiminde özel bir çalışma bulunmamaktadır (Çınar ve diğerleri, 2009; Ege, 2014).

Avrupa'daki ulusal eğitim sistemlerine kıyasla, Türkiye'de AB üyeliğini hedefleyen devlet okulları, kaynaklar bakımından en az özerkliğe, okul personelinin atanmasına, ders kitabının seçilmesine, öğretim süresine ve öğretilecek programların seçimine sahip gibi görünmektedir. Bu durum, eğitim ile ilgili yeniliklerin derslere daha çok şekil verilmesine neden olmaktadır. Türkiye'de eğitim sisteminde inovasyonun herhangi bir zamanda herhangi bir zamanda yargılama ve uygulamalarda üstlenilmesi, zorunlu eğitimin belirlenmesi üzerine en büyük çalışma ve süredir olmuştur. Zorunlu eğitim süresinde değişikliklere yol açan faktörler, ekonomik ve bilimsel gelişmeler ve nüfus artışı olarak gösterilebilir. Cumhuriyet eğitiminin cumhuriyet tarihinin birçok döneminde zorunlu eğitim süresine ilişkin kararlar alınmasına rağmen, bir yanlış anlaşmanın geçilmesi mümkün olmamıştır. Ulusal Eğitim Sistemindeki ilkokullar ve ortaokullar, programların bütünlüğünü sağlamak için 8 yıllık ilköğretim okullarına dönüştürülmüştür. Böylece, ilkokullar ve ortaokullar kaldırılmış ve tekdüze bir program geçirilmiştir. Bu yenilikle, ulusal eğitim sistemi, öğrencileri ilgi, yetenek ve yetenekleri açısından her yöne yönlendirecek şekilde düzenlenmiştir. Bu amaçla, ilköğretim programındaki bütünlüğün desteklenmesi için eğitim programlarının hedefleri doğrultusunda hazırlık sınıfları gibi ortaöğretim kurumlarında yenilikler yapılmıştır (Çetin, 2015).

Son yıllarda Türkiye'deki eğitim alanındaki yeniliklerinden biri de, tüm kurslara ve okullara BT'nin dahil edilmesini sağlayacak "FATIH" Projesi, "Artan Fırsatlar ve Teknolojik İyileştirme Hareketi - FATiH" dır. Proje kapsamında, eğitim ve öğretimde fırsat eşitliğinin sağlanması ve okulların becerilerinin geliştirilmesi amacıyla, Bilgi-Öğretme araçları, öğrenme-öğretme sürecinde daha duyu organlarına hitap ederek derslerde daha etkin kullanıımasını sağlamaktır. Okul öncesi, ilköğretim ve ortaöğretim okullarında tüm okullara ait sınıflarda dizüstü bilgisayar, LCD Panel interaktif Kurulu ve internet ağı altyapısı sağlanması amaçlanmıştır. FATiH projesi eğitimde beş ana bileşenden oluşmaktadır. Bunlar (Çınar ve diğerleri,2009):

- Donanım ve yazılım altyapısı sağlamak

- Eğitici e-içerik sağlama ve yönetimi

- müfredatta BT'nin etkin kullanımı

- Öğretmenlerin hizmet içi eğitimi

- Bilinçli, güvenli, yönetilebilir ve BT'nin ölçülebilir kullanımını sağlamaktadır.

Donanım ve yazılım altyapısı, her bir belgedeki eğitim içeriği ile ilgili tüm bilgileri ve belgeleri içeren öğretmenlerin ve öğrencilerin elektronik içeriğe kolayca erişebildikleri EBA'da (interaktif eğitim portalı) yazıcı ve belge kamerası, etkileşimli interaktif tahta, her sınıf için kablosuz ve kablolu internet bağlantısı, öğretmenler ve öğrenciler için tablet bilgisayarlar, etkileşimli e-kitaplar bulunmaktadır. Proje kapsamında, program şablonuna gerekli açıklamaların eklenmesi ve örnek faaliyetlerin yapılandırılması ile derslerde BT'nin etkin bir şekilde kullanılması sağlanmıştır (Çınar ve diğerleri,2009).

\section{METODOLOJi}

Araştırmanın metodolojisi; öncelikle alan yazında Türkiye'deki eğitim sistemindeki sorunları ve kaynakları üzerine kurgulanmıştır. Bu konuda yapılan araştırmaların irdelenmesiyle çalışma derinleştirilmiştir.

Sonraki aşamada çalışma başığı temel alınarak eğitim sistemiyle ilişkili olarak endüstri 4.0 kavramının örgütsel getirileri açıklanmaya çalışılmıştır. Endüstri 4.0 kavramıyla ilişkili olarak da inovasyon kavram ve kapsamı ortaya konulmuştur. Bu aşamada ulusal ve uluslararası inovasyon raporları incelenerek eğitimde Avrupa ulusal eğitim sistemine kıyasla Türkiye'deki eğitim sisteminin işleyiş ve yenilikçiliğe yönelik yaptığı projelerden bahsedilmiştir. Türkiye'de değişen eğitim politikalarından ve değişen eğitim sistemi modellerinden hareketle yeni eğitim politikalarının bu dönüşüm bağlamında sahip olması gereken özelliklerine vurgu yapılmıştır.

Çalışmanın son aşamasında ise söz konusu tüm bu kavramlar bir arada ele alınarak çalışma nihai hale getirilmiştir.

\section{BULGULAR ve TARTIŞMA}

Sanayi fabrikaları, teknik alana kadar idari alandan beri hiyerarşik bir yapıya vurgu yaparak genel bir formdadır. Bu, gelecekteki sistemlerin artan karmaşıklığı ile yönetimin bazı zorluklarını beraberinde getirmektedir. Bunlar üretken sistemler, bakım ve hatta iş modelleri sunduğu için karmaşık ve doymuş yönetim sistemleri gerektirir. Bu, verilerin genel bir şekilde yönetilmesi için değerlerin doygunluğunu gerektirecektir. Bu sistemler multidisiplinerdir ve çoğunluğu sınırlı birlikte çalışabilirliğindedir. Gelecek, sanayi alanındaki örgütsel yönetim düzeyindeki zorlukları beraberinde getirmektedir. Ürün, süreç ve fabrika yaşam döngüsünü senkronize etmek için mevcut araçlarla gerçekleştirilecek verimli sistemlere, süreçlere ve ürünlere yenilikçi bir entegrasyona ihtiyaç vardır (Arslan,2004).

Verimli bir iletişim ağı ve veri iletimi için gerekli fiziksel bir yapıya sahip olmanın gerekliliği, en çeşitli endüstriyel bağlamlarda daha büyük bir hareket özgürlüğü sağlar. Endüstriyel ekipman ve düzenlerdeki mevcut karmaşıklık, araçların sürekli yeniden düzenlenmesini zorunlu kılar. Kablosuz Sensör Ağı kurmak, Nesnelerin İnternetini sağlayan temel bir teknoloji haline gelir. 
Bunlar, ağ iletişim ağına bağlanarak, bu iletişim ağını daha yüksek bir sisteme entegre ederek kablosuz iletişim yoluyla ağdaki sensörleri ve aktüatörleri bağlar. Bu ekipmanlar genellikle hafif, ucuz, dağııımı ve bakımı kolaydır. Bunlar, yalnızca mevcut işlemciler ve diğerlerinin enerji kaynakları olarak doğru işleyişi için gerekli olan kaynaklarla sınırlı bir işlevsel kapasite sergilemektedir. Bunun için doğru bir işlevsellik oluşturmak için gerekli olması gerekir. Özellikle iletişim güvenilirliği seviyesinde ihtiyaçların karşılanmasına olanak tanıyan mimarlık ve protokollerin geliştirilmesine intiyaç duyulmaktadır. Geniş Alan Ağı, sensörlerdeki bilgileri harici varlıklar veya merkezi kontrol ile iletişimde aracı olarak toplar(Luecke,2008).

Kavramın tam gelişimi için, tüm sistemlerin üç temel değişkende kendi aralarında aynı düzeyde bir gelişim içinde olmalarını gerektirir: Entegre Zeka, iletişim altyapısı ve etkileşimdir. Ayrıca, akıllı unsurların akıllı olmadıkları anlaşılmalıdır, çünkü bunların insanlar tarafından önyargılı eylemler tarafından yaratılan kapasiteleri vardır. Örnek olarak, Yakın Alan İletişimi gibi radyo dalgası iletişimleri, cihazlar arasında fiziksel bir dokunuşla iletişim kurulmasını veya yakınlık bölgesine girilmesini sağlar. Radyo Frekans Tanımlaması, fiziksel bir bağlantıya veya görsel aralığa ihtiyaç duymadan, gerçek zamanlı olarak okuyucunun yaklaşımı ile uygulanan verileri aktarmak için radyo dalgaları elektromanyetik alanında elektronik frekans kullanır. Bunlar, fiziksel unsurların Nesnelerin İnterneti'ne entegrasyonunu sağlayan destek iletişim teknolojilerinden bazıları olmaktadır. Endüstriyel Siber Fiziksel Sistemler bu entegre iletişim ağını bütünleştirerek, gerekli tüm ekipman ve sistemlerin gerçek zamanlı yönetimini sağlamak için gereken operasyonel kabiliyeti sağlamaktadır. Bunlar, bir insan operatörünün doğrudan müdahalesine gerek kalmaksızın, gerektiğinde yeniden düzenleme, esneklik ve yeniden düzenleme yeteneğine izin verir. Bunlar aynı zamanda, baz ağa bağlı sensörler kullanılarak çeşitli endüstriyel ekipman, araç, makine ve işbirliği sistemleri arasında iletişim kurma becerisine sahip olmaktadır. Bunlar iki tür iletişimi mümkün kılar: fiziksel unsurlar arasındaki doğrudan iletişim veya fiziksel unsurun yapı ile iletişimi, bu tür bir entegre iletişim, akıllı yönetim sisteminin yapısının bir parçasıdır. Bu gömülü işlemciler, aktüatörler, cihazlar veya bilgisayarlar ile yapılır(Ersoy,2016).

Bilgiye dayalı üretimin yeni gereksinimleri için, mühendislik alanında çok disiplinli ve entegre becerilerin sanal, dijital ve endüstriyel süreçlerdeki iş modellerinin değişimi ile tanıtılması gerekmektedir. Bu, katma değeri yüksek ürünlerin üretilmesinde, daha karmaşık görevlerin yönetimi yoluyla, verimlilikteki artışa ayak uydurabilmektedir. Bu tür ortamın amacı, fiziksel sistemlerin dijital, bu kadar etkin ve sektörde çalışabilmeleri için yetkin bir şekilde entegre edilmesi için kalifiye personel sağlama intiyacına yansımaktadır. Yeni çözümlerin dinamik gelişimi ve mevcut durumun iyileştirilmesi, iş modelinde yatay bir yapıda bilgi ve bilgi alışverişi kapasitesiyle birlikte bir temel ilke haline gelir. Fabrikalar, endüstriyel ortamın akademik birimle doğrudan bütünleşmesi için bir platform haline gelecektir. Araştırma, eğitim ve yeniliğin ortak bir çerçevede gerçekleştirdiği faaliyetler arasındaki bilgi üçgenindeki bir paradigma, gerçek zamanlı olarak eğitim ve endüstri deneyimi sağlayacaktır. Bu, fiziksel ve sanal didaktik ekipman kullanılarak yapılacaktır, böylece gerçek endüstriyel problemlerin çözümü için bir araştırma ve deney için bir laboratuvar olarak aynı anda kullanılabilir ve bu da inovasyon seviyesine yarar sağlamaktadır (Adıgüzel, 2011).

\section{Şekil 5: Küresel Üretim Endeksi}

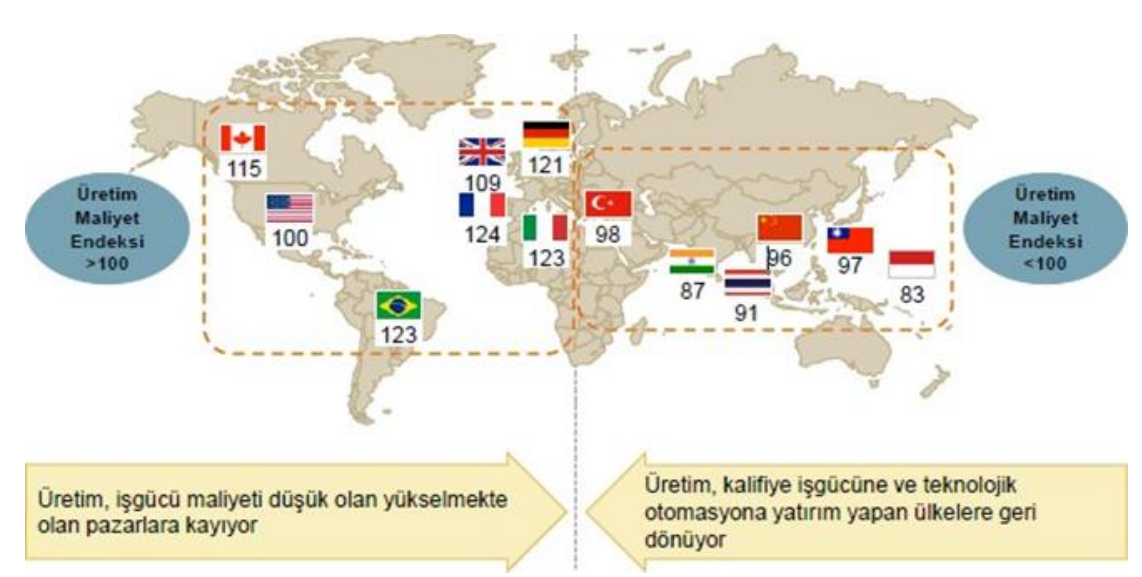

Kaynak: TÜsiAD ve BCG (2016).

Türkiye'de üretim istatistikleri incelendiğinde, ekonominin genellikle düşük katma değerli ürünler üreten düşük veya orta teknolojiye bağlı olduğu ve bu durumun ekonomik büyümenin olumsuz etkilediği görülmektedir. Son zamanlarda, küresel ve bölgesel krizlere karşı ciddi bir ekonomik zarara uğramadan tecrübeli, tepsi büyümesine ve Türkiye'ye, küresel rekabet politikasının gelişmesine izin verecek yeni sanayi devrimindeki yerini kaybettikten sonra özel ihtiyaçlar doğurmaktadır. Düşük katma değerli üretim ve genellikle ARC Dev endüstrisinin ikinci nesil modelleri kullanılarak yapılmakta olan Türkiye, trap olarak adlandırılan ekonomik orta gelirli ya da orta seviyeli bir teknolojide hapsedilmektedir. Türkiye'nin bu durumdan 
kurtulması, ürün kalitesini ve hizmetini geliştirmek için yatırım ortamını iyileştirmek, AR-GE ve inovasyon, yüksek katma değer, yüksek teknoloji ürün ve hizmetler ile ihracat ihtiyacı ile gerçekleştirilmektedir (EKOIQ, 2014).

Türkiye'nin ekonomisindeki orta gelir tuzağını aşmak ve yeni dalgaya cevap vermek ve yakma işini yasaklamak için AR-GE yatııımı son derece değerlidir. Dördüncü sanayi devrimi, yalnızca makine ve bilgi teknolojileri altyapısının kurulması ve bu iki teknolojiyi bir araya getirebilecek nitelikli bir işgücünün yetiştirilmesi nedeniyle gerçekleşebilir. Bu niteliklerin ve yeterliliklerin her biri için, Ar-Ge ve yenilikçi üretim faaliyetlerinin desteklendiği kuruluşlar kurulmalıdır. Ar-Ge, genel olarak bilgi ve teknoloji kullanarak yeni ürünlerin yaratılması ve geliştirilmesi ve yeni üretim tekniklerinin uygulanması olarak tanımlanmaktadır. Ar-Ge harcaması, üretim, hizmet, iş, ihracat, ulusal armağan, eğitim, yönetişim ve diplomaside yansıyan çok yönlü bir kavramdır. Dördüncü sanayi devrimi için, Ar-Ge harcamaları gelişmiş ülkelerin sağladığı fonlardan görülebileceği gibi ülkelerin kalkınma düzeyini gösteren bir olguya dönüşmektedir. TÜBiTAK, Ulusal Yenilik Sistemi adı altında, GSYiH hedeflerinin en az\% 3'ünü oluşturan Ar-Ge harcamaları gibi iddialı hedefler açıklamasına rağmen, son on yılda bu harcamalar\% 0,53'ten\% 0,92'ye düşürülmüştür. Tam zamanlı Ar-Ge personeli sayısı 300.000 hedefin oldukça altında 80.000 ile sınırlıdır (Çeliktaş ve diğerleri, 2015).

Türkiye 2023 yılında dünyanın en iyi 10 ekonomisi için yıllık ortalama yüzde 8,5 oranında büyümesi ve Türkiye'nin küresel ve bölgesel bir güç haline gelmek için, yeni üretim teknolojilerinin bilgisi endüstriyel sistemlere entegre edilecek, teknoloji ve yetenekli işgücü boşluğu kapatmalıdır. Dördüncü sanayi devriminin her geçen gün artmasıyla klasik üretim ilişkilerinin artması, Türkiye gibi üretici ülkelerin orta ve düşük maliyetli olması, basit teknolojilerle tehdit etmektedir. Bu problemin üstesinden gelmek için, Türkiye'nin bilişim teknolojilerindeki Ar-Ge ve eğitim politikalarının anlaşııması ve entegre edilmesi gereken endüstriyel konularında yeniliğe odaklanması gerekmektedir. Toplumsal inşanın en temel kurumlarından biri olan eğitim, modern insanlık tarihini değişime uğratıp, endüstriyel dönüşümleri ortaya çıkaran ve dönüştüren bir kurum olarak değiştirmeye devam etmektedir. Modern toplumların ortaya çıkmasına yol açan nedenlerin tetikleyici kurumlarından biri olan eğitim, sosyal kurumlar ve üretim ilişkilerinden etkilenmekte ve etkilenmektedir. Bu eğitim çerçevesi, yaşayan sanayi devrimlerinin sonuçlarından etkilenerek dönüşmekte ve endüstriyel dönüşüm ihtiyaçlarının kurumsal gelişimi için etkin bir sorumluluk üstlenmektedir. Sanayileşmiş toplumlarda, üretim derneklerinin iş konusunda uzmanlaşmış olması gerekmektedir ve eğitim kurumları, kitlesel eğitimi ön plana çıkararak standartlaştırılmış eğitim programları geliştirmeye başlamıştır. Fiziksel doğanın toplumsal hedeflere dönüşmesini sağlayan emeğin, karşılaştığı sorunları çözmek için nedensellik temelinde bilimsel üretime ihtiyacı vardı ve bu ilişki her geçen gün daha da güçlenerek iki kuruma bağlanmıştır (Dikkaya ve Özyakışır, 2006; Yazıcı, 2010; Özdemir, 2011).

Günümüzün bilgi çağını veya bilgi çağı olarak tanımlanan endüstriyel dönüşüm dalgası, üretim için temel bir bilgi kaynağıdır, bilgi üretimi ve dağıtımı konusunda çalışanların çoğunluğunun sürekli olduğu bilgi üretimi ve iletişiminde yaygın olan yeni bir üretim ilişkisi. Sürekli öğrenme, bilgi ve teknolojik gelişmenin değişmesi kaçınılmazdır. Yeni sanayi toplumlarında bilginin merkezi rolü, eğitim kurumunu endüstriyel kalkınma ve kalkınma için vazgeçilmez bir konuma yerleştirmektedir. Bilgi teknolojisine dayalı yeni bir sosyal ilişki ve üretim teknolojisi gelişirken, eğitim kurumunun klasik sanayi toplumlarını oluşturan altyapısını değiştirmesi ve kendini yeni toplumun ihtiyaçları doğrultusunda dönüştürmesi gerekiyor. Yeni eğitim politikalarının bu dönüşüm bağlamında sahip olması gereken özellikler arasında şunlar sayılabilir (Balay, 2004):

- Eğitim politikaları bilgi teknolojilerinin değişimi için uygun eğitim programları geliştirmelidir,

- Bireylerin karşılaştıkları sorunları değerlendirmek, özgürce düşünmek, tartışmak ve araştırmak için eğitim ortamını hazırlanmalıdır,

- Teknolojik gelişmedeki hızı göz önünde bulundurarak, eğitim süreçleri sadece belli bir eğitim dönemi ile sınırlı olmamalı ve yetişkinler sürekli bir eğitim sürecine tabi tutulmalıdır,

- Ezberleme ve dönüşüm algılarına dayalı temel bilgileri vermek yerine, konuların ve olayların derinlemesine ve araştırılmasına dayanmalıdır,

- Öğrenmeyi öğrenen bireylerin sayısını artırmanın yanı sıra, eğitim kurumlarında verilen bilgilerin karşılaşılan tüm sorunları çözmek için yeterli olması gerekmektedir,

- $\quad$ Eğitimde sözel ve sayısal zekayı geliştirmek yerine, görsel, kinestetik, ritmik ve benlik gelişimini içeren çok yönlü zihin gelişimini hedeflemektedir.

Eğitim süreçlerinin ölçtüğümüz sanayi devrimi ölçeğinin yeniden gözden geçirilmesi gerekmektedir. Endüstriyel kolektif eğitim modelinden bilgi toplumu eğitim modeline geçilirken değiştirilmesi gereken gruplar arasında öğretmenler, öğrenciler ve yöneticiler vardır ve vakalar arasında öğrenme yöntemi, öğrenme stili, eğitim programları ve başarı kriteri gibi unsurlar bulunmaktadır. Dördüncü dalga eğitim modeline uygun politikalar geliştirilirken, sanayi toplumlarındaki eğitim merkezindeki toplu ve standart eğitim politikaları her geçen gün daha fazla sorgulanmaktadır. Bu belirtilen parametreler ve giderek artan 
kurumsallaşmış eğitim kurumu çerçevesinde, öğrenci yeteneklerine odaklanan ve bireysel ihtiyaçlara ve ihtiyaçlara öncelik veren bireysel eğitim politikalarının tasarlanması çok değerlidir (Toffler, 2008).

Türkiye'nin dördüncü sanayi devriminin eşiğinde bulunması, endüstri altyapısının ve nitelikli insan gücünün eğitim sisteminin karşılaştığı sorunları göz önünde bulundurarak özellikle eksiklikleri gidermek ve bu eksiklikleri giderebilecek politikaların geliştirilmesi çok önemlidir. Hem gençlerin hem de yeni kuşağın hem ruhsal hem de kültürel değerlerin yanı sıra özgür ve bilimsel düşünce gücü ile büyüdüğü ulusal bilinç tarafından kullanılabilecek evrensel bir bilince sahip olmayı amaçlamaktadır. Fakat bu eğitim politikası yaklaşımı, ikinci dalga sanayi toplumlarının ürünü, küreselleşmeden oldukça fazla etkilenmiş ve kitlesel eğitimin tartışıldığı yeni eğitim paradigması karşısında yeniden gözden geçirilmesi gerekmektedir. OECD'ye bağlı ülkeler tarafından periyodik olasılıklar arasında 2012 yılında Pisa testi yapıldığında, sonuçlar Türkiye bilim, matematik ve okuma yeterlilik testi sırasıyla 43,44 ve 42 'dir. Türkiye'de uzun yıllardan beri küresel iktisadi alanda ilk yirmi yıla girmesine rağmen, bu sonuçlara ulaşıımakta olan eğitim programında ciddi bir problem oluşturmaktadır. Türk eğitim sisteminin işleyişi ve kalite ve öngörülen hedeflerin eksikliği iki ana etkene dayanmaktadır. Bunlar; bürokratik yönetim ve sosyo-kültürel yapıdır (OECD, 2012; EBSO, 2015).

Türk eğitim sistemi, ikinci sanayi devrimi, endüstriyel toplumun ihtiyaçlarını karşılamak için düzenlenen bir eğitim modeline sahiptir. Dördüncü dalga sanayi devrimi ve nitelikli işgücünün teknik altyapısını oluşturmak için bu eğitim modeli terk edilmeli ve bilgi toplumu eğitim modeli terk edilmelidir. Bu iki eğitim modeli ile politika oluşturmanın gerekli olduğu alanlar arasındaki farklar Tablo 1'de verilmiştir.

Tablo 1: Türkiye'deki Değişen Eğitim Sistemi Modelleri

\begin{tabular}{|c|c|c|}
\hline Ölçütler & Sanayi Toplumu Eğitim Modeli & Bilgi Toplumu Eğitim Modeli \\
\hline Öğretmenin Rolü & $\begin{array}{l}\text { Herşeyi bilen öğretmen, bilgi aktarımı } \\
\text { alanında uzman }\end{array}$ & Yönlendirici, yol gösterici öğretmen \\
\hline Öğrencinin Rolū & Dinleyici, edilgen, bireysel çalıșma & Aktif, işbirliğine dayalı takım çalışması \\
\hline Yöneticinin Rolü & Yönetim lideri & Öğretim-yönetim lideri \\
\hline Öğrenme Yöntemi & Sınıfta öğrenme & Kişisel araştırma \\
\hline Öğrenme Șekli & Bireysel çalışmayla öğrenme & Takım çalışmasıyla öğrenme \\
\hline $\begin{array}{l}\text { Eğitim } \\
\text { Programları }\end{array}$ & Standart eğitim programları & Değişken eğitim programları \\
\hline İsgören Geliştirme & Hizmet-içi eğitim & Örgütsel öğrenme \\
\hline Başarı Ölçūtü & Ezberlenmiş bilgi aktarımı & $\begin{array}{l}\text { Kavramları çok boyutlu olarak } \\
\text { tanımlayabilme }\end{array}$ \\
\hline
\end{tabular}

Kaynak: Balay, 2014

Dördüncü sanayi devrimi eğitim programı, eğitim, düşünce, tartışma ve araştırma ortamı, yaşam boyu eğitim, öğrenme öğretimi, bireysel analiz ve sentez, problem çözme ve iletişim, mesleki değerler ve etik değerler gibi bilgilere dayanmaktadır. Disiplinlerarası çözümler bulmak için sorumluluk ve entelektüel esneklik elde etmek. Bu hedeflere ulaşmak için öncelikle bilgi toplama uygun bir eğitim modeli olarak kabul edilmeli ve bu eğitim modeline uygun politikalar geliştirilmelidir(Aybars, 2016).

\section{SONUÇ}

İnsanlık tarihinin doğal gelişimi, yeni bir endüstriyel dalgayı topluma kazandırmak için bilgi ve iletişim teknolojilerinin sunduğu fırsatlardan yararlanmaktadır. Modern toplumların ortaya çıkmasına yol açan kasların gücüne dayalı emek kavramı, üretim aşamasından çıkarılırken, ortaya çıkan uçurum, yapay zeka, makine-teçhizat kullanarak kendi kararlarını verebilen akıllı makineler tarafından doldurulmaktadır. Yeni toplumsal düzende, insanlar kas güçlerinden ziyade zihinsel birikimleri ile konumlarını ifade etmektedir. Özellikle Almanya olmak üzere gelişmiş ülkeler tarafından yürütülen uygulama uygulamalarının ve Ar-Ge faaliyetlerinin teşvik edildiği Endüstri 4.0; Kaynak tüketiminin azaltılması, enerji verimliliği, üretimde üretkenlik, azalan işgücü maliyetleri ve toplumun yaşlanması üretimi etkilemez. Değirmenlerin ve sanayi devriminin akıllıca gelişmesi, elverişli bir işgücü piyasasının yaratılmasıyla ilgili sorunlara sahiptir, ancak teknolojik gelişmeler ve hükümetlerin verdiği destek, gerçekleşme tarihini ön plana çıkarmıştır. Türkiye, bu devrim niteliğindeki teknolojinin üretim ve sanayide, eğitimden Ar-Ge faaliyetlerine kadar olan değişimleri yakalamak için üretilmesi ve pazarlanması, birçok alan dahil olmak üzere ciddi politikalar geliştirmelidir. Bu nedenle, 14 Ocak 2016 tarihinde gerçekleştirilen yeni Ar-Ge Reform Paketi, Ar-Ge faaliyetleri için gelişmiş ekonomilerin teşvik ve desteklerine göre oldukça yetersiz kalmaktadır.

Türkiye'nin ekonomik ve eğitim altyapısı, yönetmelikler ve bu alanlarda yapılan politika tavsiyelerinin değişimi açısından faydalı sonuçlar vermesine rağmen, genel olarak birbiriyle ilgili bir program çerçevesinde organizasyon görülmektedir. Endüstriyel dönüşümün gerekliliği politika yapıcılar, üreticiler ve toplum tarafından kabul edilmeli ve çözüm arayışında ortak bir akıl oluşturmak için özen gösterilmelidir. Bu aşamanın ardından, endüstriyel inovasyonların uygulanabileceği sektörler 
belirlenmeli ve bu sektörler tüm ekonomik sistemi değiştirmek yerine odaklanmalıdır. Bu sektörlerin ihtiyaç duyduğu bilgi, teknoloji ve nitelikli insan altyapısını sağlamak için eğitim sisteminin bilgi teknolojisinin eğitim modeline göre yeniden düzenlenmesi gerekmektedir. Bu müdahalelerin her biri ayrıntılı olarak değerlendirilmeli ve bu değerlendirme sonucunda gerekli ve gerekli alt politikaların geliştirilmesine özen gösterilmelidir. Dördüncü sanayi devrimi olan Türkiye'nin ekonomisi, hem olumlu hem de olumsuz etkileme potansiyeline sahiptir. Türkiye, eğitim altyapısı ve endüstriyel bilgi işlem ve iletişim teknolojileri çerçevesinde dönüştürülemezse, gelişmiş ülkelerdeki verimliliğin artmasıyla küresel rekabet gücünü kaybetme tehlikesi ile karşı karşıya kalmaktadır. İkincisiyse, bilgi toplumunun başarılı bir şekilde yapılandırılması gerekiyorsa, ekonomideki verimliliğin artıııması, büyüme, istihdam ve Türkiye'nin ekonomisine yatırım yapılması hedeflerine ulaşmaktadır.

\section{KAYNAKÇA}

ACATTECH (2013). Recommendations for implementing the strategic initiative Industrie 4.0. German National Academy of Science and Engineering.

Açan, T. (2004). Process and success factors of innovation in Turkish-German joint ventures. (Unpublished Master Thesis), I.T.U. Institute of Science and Technology, İstanbul.

Adıgüzel, M. (2011). Uluslararası rekabet gücü: belirli faktörler ve ölçülmesi, Türkiye bağlamında bir değerlendirme. Ankara: Nobel Yayıncılık.

Arıkan C. (2003). Ulusal inovasyon sistemi: kavramsal çerçeve Türkiye incelemesi ve ülke örnekleri. Tüsiad Yayınları.

Arpacı, i. (2009). Technological innovation model for public sector. (Unpublished Master Thesis), Orta Doğu Teknik Universty, Institute of Science and Technology, Ankara.

Aslan, K. (2004). Küreselleşmenin eğitim boyutu. Ege Eğitim Dergisi,vol. 5, pp.1-5.

Aybars, H. (2016). Dijital evrim ile endüstri 4.0. BT Haber Dergisi, vol. 1076, pp. 17-24.

Balay, R. (2004). Küreselleşme, bilgi toplumu ve eğitim. Ankara Üniversitesi Eğitim Bilimleri Fakültesi Dergisi, vol.37, no.2, pp.61-82.

Casper, S. \& Waarden, F. (2005). Innovation and institutions: a programmatic study. Cheltenham, UK.

Çeliktaş, M.S., Sonlu, G., Özgel, S. \& Atalay, Y. (2015). Endüstriyel devrimin son sürümünde mühendisliğin yol haritası. TMMOB Makina Mühendisleri Odası Mühendis ve Makine Dergisi, vol. 56, no. 662, pp24-34.

Çetin, O.U. (2015). Küreselleşmenin eğitimin farkli boyutlari üzerindeki etkileri. Çağdaş Yönetim Bilimleri Dergisi, vol 1, no.1, pp. 1-19.

Çınar H., Döngel N. \& Söğütlü C. (2009). A case study of technical and vocational education in Turkey. Procedia Social and Behavioral Sciences vol.1, pp.160-167.

Dağlı, A. (2007). Küreselleşme Karşısında Türk Eğitim Sistemi. Dicle Üniversitesi Ziya Gökalp Eğitim Fakültesi Dergisi, vol.9, pp.1-19.

Dikkaya, M. \& Özyakışır, D. (2006). Küreselleşme ve Bilgi Toplumu: Eğitimin Küreselleşmesi ve Neo-Liberal Politikaların Etkisi. Uluslararası ilişkiler Dergisi, vol.3, no.9, pp.151-172.

Ege, B. (2014). 4. endüstri devrimi kapıda mı? Bilim ve Teknik Dergisi, vol.558, pp.27-29.

EKOIQ (2014). Akıllı yeni dünya: dördüncü sanayi devrimi. EKOIQ Dergisi Özel Eki.

Ersoy, A.R. (2016). Endüstri 4.0 sürecinde neredeyiz? Endüstri 4.0 Platformu. http://www.endustri40.com/endustri-4-0-surecindeneredeyiz/

Hobikoğlu, E.H. (2009). Yeni ekonomide inovasyon ve sürdürülebilir rekabetin yarattığı katma değerin bilgi toplumunda etkisi. (Yayınlanmamış Doktora Tezi), İstanbul Üniversitesi Sosyal Bilimler Enstitüsü, İstanbul.

KAYSO (2015). Sanayi 4.0: akıllı üretim geliyor. Kayseri Sanayi Odası Bilgi Dergisi, vol. 107, pp. 36-45.

Luecke R. (2008). Managing Creativity and Innovation. Harvard Business School Pres.

Looney J. W. (2009). Assessment and innovation in education. OECD Education Working Papers, No. 24, OECD Publishing. http://dx.doi.org/10.1787/222814543073

OECD (2012). PISA 2012 results in focus: what 15-year-olds know and what they can do with what they know. https://www.oecd.org/pisa/keyfindings/ pisa-2012-results-overview.pdf

Özdemir, S.M. (2011). Toplumsal değişme ve küreselleşme bağlaminda eğitim ve eğitim programlari: kavramsal bir çözümleme. Ahi Evran Üniversitesi Eğitim Fakültesi Dergisi, vol.12, no.1, pp.85-110.

Patrinos H.A. \& Psacharapoulos, G. (2011). Education; past, present and future global challenges. Policy Research Working Paper 5616, The World Bank Human Development Network Education Team. 
Satı- Ecevit, Z. (2013). İnovasyonu Yönetmede Kesitler. Ankara: Nobel Yayınları.

Schilling, M.A. (2005). Strategic Management of Technological Innovation. New York: McGraw-Hill Publishers.

Seyrek, A.G. (2015). Endüstri 4.0 için yol haritası. Endüstri 4.0 platformu 31 Aralık 2015, http://www.endustri40.com/endustri-4-0uygulama-icin-yol- haritasi/

SIEMENS (2015). Endüstri 4.0 yolunda. Siemens Türkiye.

Şengün M., (2009). Süreç inovasyonunun verimliliğe etkisi: bir uygulama. (Yayınlanmamış Yüksek Lisans Tezi), Dokuz Eylül Üniversitesi Sosyal Bilimler Enstitüsü, İzmir.

Şimşek, T. (2016). Endüstri 4.0 ile geleceğe bakış ve beklentiler. Endüstri 4.0 platformu. http://www.endustri40.com/endustri-4-0-ilegelecege- bakis-ve-beklentiler/

Taghizadeh, K. \& Keser, G. (2015). Dördüncü sanayi devrimi: yarının fabrikaları neye benziyor? Taşıt Araçları Yan Sanayicileri Derneği Dergisi, vol.84, pp. 68-70.

Toffler, A. (2008). Üçüncü Dalga. İstanbul: Koridor Yayıncılık.

TÜBiтAK (2016). Ar-Ge reform paketi tanitim toplantisi yapildi. Türkiye Bilimsel ve Teknolojik Araştırmalar Merkezi. https://www.tubitak.gov. $\operatorname{tr} / \mathrm{tr} /$ haber/ar-ge-reform-paketi-tanitim-programi-yapildi

Tsai, K. (2005). R\&D productivity and firm size: a nonlinear examination. Technovation, vol.25, no.7, pp. 795-803.

Yazıcı, E. (2010). Dönüşen İş Kültürü: İlkçağdan Sanayi Ötesi Topluma. Ankara: A-Kitap Yayınları.

Yılmaz, A. (2014). Almanya ve endüstri 4.0. Moment Dergisi, pp 70. 